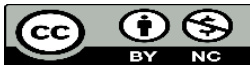

Licenciado sob uma licença Creative Commons

ISSN 2175-6058

https://doi.org/10.18759/rdgf.v19i2.1373

\title{
MASCULINIDADE E CRIMINALIDADE EM MOONLIGHT: UM ESTUDO SOBRE AS CONEXÕES ENTRE IDENTIDADE E DELINQUÊNCIA
}

\author{
MASCULINITY AND CRIMINALITY IN MOONLIGHT: A STUDY \\ ABOUT THE CONNECTIONS BETWEEN IDENTITY AND \\ DELINQUENCY
}

Adilson José Moreira

Humberto Barrionuevo Fabretti

\section{RESUMO}

Este artigo examina os motivos da violência dirigida a pessoas que pertencem simultaneamente a minorias raciais e sexuais e também as razões pelas quais ela pode levar esses indivíduos a praticar atos ilícitos. Com o intuito de compreender esse fenômeno complexo, desenvolvemos a noção de repertório identificatório, conceito que possui três significações: ele designa um conjunto de prescrições sociais que determinam as identidades que podem ser expressas no espaço público, um conjunto de representações positivas e negativas sobre grupos sociais conexos e também as condições institucionais necessárias para o alcance de objetivos pessoais. Ele será empregado para uma análise da trajetória do personagem principal do filme Moonlight, indivíduo que se torna um delinquente em função da significação social de diversas relações entre criminalidade e masculinidade em diferentes aspectos de sua vida. Essa história espelha a situação de centenas de milhares de pessoas cujo contexto de vida pode fazer com que elas recorram ao crime para que possam compensar o sentimento de frustração gerado pela violência baseada na identidade.

Palavras-chave: Identidade. Masculinidade. Criminalidade. Repertório identificatório. 


\section{ABSTRACT}

This article examines the motives of violence against people who belong to both racial and sexual minorities, as well as the reasons that may impel them to engage in illicit behavior. In order to reach this goal, we develop the concept of identity repertoire, a theoretical apparatus that designates a set of social prescriptions that determine the identities that can appear in the public space, an ensemble of positive and negative representations of connected social groups, and also the necessary institutional means to achieve various personal goals. This concept provides parameters for an analysis of the main character of the movie Moonlight, a person who engage in criminal activities as a consequence of cultural associations between masculinity and criminality. This story mirrors the situation of thousands of persons who resort to crime in order to eliminate the frustration derived from identity-based discrimination.

Keywords: Identity. Masculinity. Criminality. Edentity repertoire

\section{INTRODUÇÃO}

Este artigo analisa um tópico ainda pouco explorado nos estudos sobre criminologia no nosso país: os mecanismos responsáveis pela violência dirigida a pessoas que são simultaneamente membros de minorias raciais e sexuais. Esse pertencimento as situa em uma posição de grande vulnerabilidade por não fazerem parte de grupos dominantes construídos a partir de identidades hegemônicas. ${ }^{1}$ Acreditamos que a escolha desse tema possui grande relevância pelos motivos que passamos a elencar. Primeiro porque a cultura punitivista em voga na nossa sociedade associa a criminalidade a grupos raciais específicos, o que legitima a vigilância e a violência estatal contra membros desses segmentos (SOUZA, 2017: DIAS 2017). Segundo porque, ao pressupor a homogeneidade interna dessas comunidades, esse discurso torna invisíveis as agressões sofridas por pessoas que se encontram em uma interseção de exclusões. A violência também existe dentro de grupos minoritários e ela tem como alvo constante minorias sexuais. ${ }^{2}$ Terceiro porque a invisibilidade social dessas agressões impede a compreensão da operação de certos regimes de prescrições sociais que promovem comportamentos hostis contra 
essas pessoas e também a delinquência entre elas. ${ }^{3}$ Esses atores sociais associam a criminalidade a determinadas características, o que encobre as relações hierárquicas de poder presentes em uma dada sociedade. Em função disso, as estruturais sociais que produzem a criminalidade contra e por certos grupos minoritários continuam operando sem questionamento.

Tomaremos como objeto de estudo deste trabalho a história de Chiron, personagem principal do filme Moonlight, obra que adquiriu grande visibilidade por ser uma das primeiras produções cinematográficas a examinar o problema da violência contra pessoas que são duplas minorias. Poucos assuntos têm sido tratados de forma tão extensa no cinema quanto à questão da criminalidade, o que permite a circulação de discursos sobre a suposta periculosidade dos vários grupos sociais. ${ }^{4}$ Correlações entre raça e masculinidade são elementos constitutivos das mensagens presentes em inúmeros filmes: a raça dos personagens geralmente determina o tipo de valoração social de cada um deles. Se membros de minorias raciais são quase sempre representados de forma negativa, os que pertencem ao grupo racial dominante são retratados de maneira positiva na vasta maioria das vezes, mesmo quando são delinquentes. Além disso, esse processo estabelece uma hierarquia de representações de diferentes tipos de masculinidade. Isso pode ter implicações significativas, principalmente quando consideramos as discussões atuais sobre a defesa de penas mais severas como forma de controle do crime. ${ }^{5}$

Muitos atores sociais sugerem que a criminalidade decorre de disposições naturais de certos grupos, argumento baseado em um essencialismo cultural que tem forte apelo popular e que está na base no populismo penal em voga entre nós. Assim, concepções estratificadas da masculinidade em produções cinematográficas permitem a circulação de estereótipos que estimulam a violência estatal contra minorias raciais. Chiron, o personagem principal de Moonlight, enfrenta diversas formas de agressão física e psicológica ao longa da vida em função dos vários tipos de subordinação aos quais está submetido. Por um lado, ele não pode vivenciar plenamente a masculinidade como um homem negro porque esse é um tipo de identidade hegemônica à qual apenas homens brancos 
têm acesso pleno. Por outro, ele também é excluído da masculinidade negra por ser socialmente percebido como homossexual. ${ }^{6}$

Essa situação nos convida a formular uma explicação dos mecanismos culturais que promovem a violência contra membros dessa classe de indivíduos e também as razões pelas quais a delinquência pode surgir como uma alternativa para lidar com a exclusão. Uma investigação dessa natureza não pode deixar de considerar um ponto importante: narrativas e práticas culturais sobre a raça e gênero desempenham um papel importante na delinquência, motivo pelo qual devemos examinar as relações próximas entre masculinidade e criminalidade (BALL, 2016; HEINER \&COSTER, 1999; MESSERSCHMIDT, 1993). Mais do que uma forma de comportamento natural de pessoas do sexo masculino, a masculinidade é uma forma de ação social guiada por regras culturais institucionalizadas a partir das quais homens extraem sentido para seus comportamentos. A agressão contra membros de minorias sexuais e raciais é uma das situações nas quais a masculinidade se liga ao crime. Masculinidade e criminalidade são fenômenos que atuam em grande parte como meios de controle social, razão pela qual acreditamos ser necessário explorar suas relações no contexto da violência contra membros de minorias sexuais e raciais (MESSERSCHMIDT, 1993). Este artigo tem como objetivo principal fornecer subsídios intelectuais que iluminem alguns pontos que ainda permanecem obscuros nos debates sobre a criminologia, entre eles o papel da violência e da exclusão baseada na identidade na produção social do delito.

A realidade retratada no filme Moonlight está longe de ser mera ficção. Vários estudos sobre a multidimensionalidade de opressões comprovam que ela possui ampla correspondência com a realidade de sociedades racialmente estratificadas, o caso do Brasil e dos Estados Unidos (CRENSHAW, 1989; HUTCHINSON, 1999). A multiplicidade de opressões causada pela ação simultânea do racismo e da homofobia faz com que atividades consideradas como criminosas possam ser uma alternativa para o indivíduo enfrentar a frustração pessoal constante decorrente de seu status social. A estigmatização de várias formas de identidades concorre para a criação das disparidades materiais entre eles. 0 filme nos convida a prestar atenção especial às correlações entre 
identidade de gênero, identidade sexual e identidade racial, fatores que consideramos ser extremamente relevantes para a análise da criminalidade contra e dentro desse segmento social específico, minorias dentro de minorias. 0 filme lança algumas luzes sobre os motivos pelos quais alguns homens afirmam a masculinidade por meio do crime, um ponto que a teoria tradicional da criminologia ainda não pode explicar de forma satisfatória. Além disso, ele também sugere que esta manifestação específica da criminalidade está fortemente associada a sentimentos de frustração pessoal, razão pela qual precisamos entender as relações entre estruturas sociais e comportamento delinquente.

Para investigarmos os meios pelos quais arranjos sociais fomentam a violência contra membros desse segmento social e também os que os conduzem à delinquência, nós utilizaremos o conceito de repertório identificatório formulado por Erik Erikson, noção que será acrescida de outras teorias para expandir seu poder explicativo. Este termo designará neste trabalho um construto teórico que engloba três aspectos distintos, mas complementares. Primeiro, ele indica um conjunto de prescrições sobre manifestações aceitáveis de certas identidades no espaço público. Parte-se do pressuposto de que apenas identidades hegemônicas podem ter visibilidade nesse domínio, sendo que violações a essa regra podem suscitar a violência. 0 termo designa então um sistema de controle social sobre os corpos e comportamentos nos diversos planos de interações humanas (CONNEL, 2007; BRICKEL, 2012). Segundo, ele engloba um conjunto de representações culturais positivas e negativas de grupos sociais. Essa dimensão cultural estabelece critérios para aqueles que podem ter acesso aos meios institucionais necessários para uma vida autônoma (ERIKCSON, 1966). Terceiro, ele também contempla os meios institucionais abertos aos indivíduos para que eles possam alcançar seus objetivos (AGNEW, 1984). 0 acesso a eles está diretamente relacionado às representações sociais sobre esses grupos; o nível de apreço social que eles possuem determinam as oportunidades materiais que lhes são abertas (DARWALL, 1977; FREDMAN, 2007).

Como afirmamos anteriormente, a noção de repertório identificatório aqui elaborada expande o conceito proposto por Erik Erikson, psicanalista que devotou grande atenção ao tema da identidade. Esse termo 
designa, dentro de sua teoria, as referências culturais que permitem os indivíduos construírem um senso de identidade ao longo das diferentes fases do desenvolvimento moral. Embora ele forneça elementos importantes para examinarmos a situação de Chiron, ele incluirá outros elementos teóricos. Utilizaremos, em primeiro lugar, certos pressupostos da teoria de criminalidade proposta por Robert Agnew, autor que investiga o papel de interações sociais negativas na criminalidade contra e entre membros de grupos sociais. Discutiremos depois os conceitos de discriminação interseccional e de discriminação estrutural, o que nos permitirá entender os mecanismos que promovem a condição subordinada das formas de status social de certos grupos. Também abordaremos a noção de identidade de gênero como um tipo de performance social definida a partir de parâmetros socialmente estabelecidos. Devemos dizer que não pretendemos propor aqui uma explicação geral da delinquência, mas, sim, apresentar uma referência teórica para análise do problema específico dos crimes cometidos contra e por indivíduos que são socialmente excluídos em função do conflito entre identidades hegemônicas e identidades subordinadas. Mais especificamente, propomos o conceito de "repertório identificatório" que poderá ser relevante para o estudo da violência dirigida a pessoas que são membros, simultaneamente, de minorias sexuais e raciais.

A primeira parte deste artigo examina o discurso sobre o sujeito social dentro do pensamento criminológico. Estaremos interessados em investigar os fatores que causaram a transformação das representações sobre o sujeito criminoso e da motivação do crime. A segunda parte explora o tema da identidade no pensamento de Erik Erikson, psicanalista que afirmou a centralidade da questão da identidade para a psicanálise e que também esteve atento às consequências do racismo na formação da identidade das pessoas. Em seguida, falaremos sobre os elementos centrais da teoria do racismo estrutural, tema que nos auxiliará a entender o contexto no qual o tema da identidade negativa é construído. A parte seguinte discorre sobre a ideia do gênero como um tipo de prescrição social que exige um tipo específico de performance pessoal. Essas teorias nos auxiliarão a expandir o conceito de repertório identificatório proposto 
por Erik Erikson, conceito que conduzirá a nossa análise sociológica do filme Moonlight.

\section{O DISCURSO SOBRE 0 SUJEITO DENTRO DO PENSAMENTO CRIMINOLÓGICO}

Por quase toda história do pensamento criminológico é possível identificar um sujeito a quem se atribuí o caráter de "criminoso", variando sua definição de acordo com a orientação ideológica de cada teoria. As teorias criminológicas podem ser divididas conforme critérios variados, sendo que um dos mais comuns é o que distingue entre criminologias do consenso e criminologias do conflito. Os tributários das primeiras não concebem a sociedade como um conflito, partindo do pressuposto de que há um consenso mínimo entre os membros das sociedades e, consequentemente, não analisam criticamente os processos de criminalização e as definições do que seja ou não considerado como "crime", considerando-o como um elemento neutro. Já os adeptos das segundas teorias partem do princípio de que não há consenso na sociedade, sendo o conflito uma constante, de modo que os processos de criminalização e as próprias definições de crime são fruto dessa disputa permanente, sem qualquer possibilidade de neutralidade na sua criação e, consequentemente, aplicação. A formação do "sujeito criminoso", portanto, vai depender de como a respectiva teoria criminológica concebe o crime, seja como fruto do consenso, seja como fruto do conflito. Por meio de uma sintética análise das principais histórias do pensamento criminológico é possível perceber como foram se formatando as diversas concepções do "sujeito criminoso" e as possíveis explicações para o fenômeno da criminalidade.

A criminologia da Escola Clássica é apontada como a primeira manifestação criminológica revolucionária, já que no século XVIII, como resultado do esgotamento do sistema feudal de produção e fortalecimento do sistema de produção capitalista, a burguesia se fortalece como classe e passa a criticar a estrutura do poder punitivo constituída pela e para a nobreza. A forma orgânica e sistematizada desta criminologia revolucionária, que tem seu fundamento basilar na ideia do contrato social, é 
representada pela Escola Clássica que, sinteticamente, defende: o crime como ente jurídico (separação definitiva entre crime e pecado e Estado e Igreja), o criminoso como detentor de livre arbítrio, e a retribuição moral como justificativa para punição.

Especificamente no que se refere à explicação etiológica do crime, Taylor, Walton e Young afirmam que discussões detalhadas sobre a natureza da motivação criminal é evitada na maioria dos escritos dos autores da Escola Clássica, pois o foco maior é na evolução do sistema legal, considerando na constituição deste um cálculo moral que circunscreve e detalha a reação social adequada em face do criminoso (TAYLOR; WALTON, 2013). A veracidade do argumento destes autores pode ser constatada na obra mais representativa deste modelo criminológico: “Dos Delitos e das Penas", de Cesare Bonesana. Posteriormente, já no final do século XIX e início do século XX, como consequência do prestígio das ciências naturais, surgem as teorias criminológicas positivistas, produzindo-se uma ruptura no pensamento criminológico ocasionada pela substituição do "crime" pelo "delinquente" como objeto de estudo, de modo que enquanto a Criminologia Clássica foi construída por filósofos e juristas; a Positivista, em seu aspecto clínico, é resultado do trabalho de psiquiatras, biólogos, psicólogos, antropólogos etc.

A criminologia positivista de cunho individualista pode ser sintetiza, nos dizeres de Anitua, no "homem delinquente", que representava o desviante como uma pessoa diferente, pertencente a outra "raça" (ANITUA, 2010, p. 179). Aponta, ainda, o referido autor, que a influência do racismo é evidente na criminologia positivista, pois quando esta se refere ao delinquente como "diferente", o que se quer indicar é que era "inferior", numa clara continuação da construção ideológica já operada no Antigo Regime, vez que os "inferiores" de agora - negros, doentes mentais etc. pertencem aos mesmos grupos que eram considerados "endemoníados" (ANITUA, 2010). A ideia da Escola Classica da responsabilidade moral e imputabilidade do delinquente é absolutamente contraposta pelo rígido determinismo biológico lombrosiano, que, posteriormente, será ampliada por Garófalo e por Ferri, que acrescentaram à equação determinista os elementos sociológicos e psicológicos (BARATTA, 2002, p. 39-44). 0 delito passa a ser, de uma forma ou de outra, o resultado da realidade 
em que a pessoa está inserida. Entre as principais críticas à concepção positivista individualista destacam-se a concepção do crime como um dado ontológico e pré-constituído à reação social e ao direito penal e o fato dos sujeitos que foram observados para a construção desta teoria já terem sido, previamente, objeto de sucessivos filtros pelo sistema penal, vez que já se encontravam nos cárceres, nos manicômios etc (BARATTA, 2002, p. 39-45).

Simultaneamente ao desenvolvimento da Escola Positivista, consolidam-se as abordagens sociológicas do crime que darão início à Sociologia Criminal, que a partir do $3^{\circ}$ Congresso Internacional de Antropologia Criminal (Bruxelas, 1892) passa a predominar, especialmente em virtude dos trabalhos de Lacassagne, Tarde e Durkheim (BARATTA, 2002, p. 40-46). A Sociologia Criminal, em oposição ao individualismo positivista, desloca a questão da explicação etiológica do crime para a sociedade, afastando, inclusive, seu caráter patológico. Como consequência da Sociologia Criminal Europeia do século XIX, desenvolveu-se, nos Estados Unidos da América, a Sociologia Criminal Americana do século XX, tendo sua forma mais acabada na Escola de Chicago. Os primeiros trabalhos sociológicos estadunidenses tinham por finalidade encontrar soluções aos problemas das grandes cidades, decorrentes, no mais das vezes, de processos de urbanização acelerados em virtude da rápida industrialização e das enormes ondas migratórias e imigratórias.

É no contexto da Escola de Chicago, que surge Robert Merton, que terá papel central no objetivo deste artigo, assumindo os paradigmas da anomia de E. Durkheim e dá continuidade à perspectiva estruturalfuncionalista convertendo-a em teoria da criminalidade e como modelo de explicação geral da criminalidade. Robert Merton reestrutura a ideia de anomia a partir da filosofia do american dream, considerando anômica a situação decorrente da diferença existente entre a estrutura cultural imposta a todas as pessoas e a estrutura social disponível que distribui as oportunidade de maneira desigual. Essa discrepância existente entre os fins culturalmente estabelecidos como válidos e os meios legítimos para alcança-los está na origem do comportamento criminoso (BARATTA, 2002, p. 63). Assim, explica-se etiologicamente o comportamento criminoso como um "atalho" utilizado por aqueles que 
estão socialmente em desvantagem utilizado para se alcançar os fins culturais desejados. Segundo Pablos de Molina os maiores méritos das teorias estruturais-funcionalistas foi destacar a normalidade do delito e sua inextirpabilidade, porém, por outro lado, concebem a sociedade de forma monolítica, consensual e compartilhadora dos mesmos valores, fatos que serão contrapostos pelas teorias dos conflitos que as sucederam (PABLO DE MOLINA, 2013, p. 126).

As teorias que buscam explicar a criminalidade a partir das classes baixas, também chamadas de estruturalistas, foram objeto de muitas críticas, especialmente pela generalidade e limitação de suas explicações etiológicas que demonstraram-se incapazes de explicar satisfatoriamente três fatos: a existência de significativa criminalidade das classes médias e altas; o abandono do comportamento criminal por parte significativa dos jovens que alcançam a maturidade; e que nem todos os jovens das classes baixas repudiam os meios e procedimentos legítimos de acesso ao bem estar e integram-se a uma subcultura (PABLO DE MOLINA, 2013, p. 132). Atualmente, várias destas teorias criminológicas subsistem e dividem espaço na academia e na prática forense procurando demonstrar a validade de suas assertivas. Porém, ao que nos parece, por ser o crime um fato complexo que pode ter as mais variadas explicações ou simplesmente não ter explicação alguma, dificilmente uma teoria conseguirá se sobrepor definitivamente sobre as outras. Inegável, entretanto, que algumas propostas teóricas são mais plausíveis, enquanto outras sequer podem ser seriamente admitidas no século XXI. De um ponto de vista generalista, as teorias do conflito social nos parecem mais acertadas, pois enxergam a sociedade e as relações que se desenvolvem em seu interior de forma mais realista.

Entretanto, não obstante as ressalvas feitas previamente, no presente artigo propõe-se uma abordagem do protagonista da película Moonlight à partir da teoria criminológica de Robert Merton, mais especificamente sobre uma extensão de sua teoria formulada por Robert Agnew, combinada com a teoria de Erik Erikson sobre os repertórios identificatórios. A realização dessa abordagem teórica não significa, absolutamente, que compreendemos serem as teorias de Robert Merton ou de Robert Agnew as mais corretas e completas sobre a criminalidade. Entretanto, parece- 
-nos ser possível um recorte epistemológico e a utilização destas teorias como forma de complementação da teoria de Erik Ericsson para uma análise da interseccionalidade entre masculinidade, homossexualidade e criminalidade, tal qual apresentada no filme Moonlight.

\section{A TEORIA DA CRIMINALIDADE DE ROBERT AGNEW}

Pensamos que as teses proposta por Robert Agnew oferecem elementos importantes para examinarmos a situação daqueles que são vítimas e também são conduzidos à criminalidade em função do estresse produzido pela violência baseada em traços identitários. A escola funcionalista, corrente à qual ele está filiado, teve um papel significativo no avanço dos estudos sobre o crime. Seus autores rejeitaram explicações tradicionais do delito como produto da inclinação pessoal e afirmaram que a delinquência deve ser vista como um problema criado pelas estruturas sociais. Robert Merton argumentou em seus escritos que a anomia ocorre por casa da distância entre valores culturais vigentes e os meios institucionais disponíveis para seu alcance pelos membros dos diversos grupos sociais. Portanto, a atividade criminosa deve ser entendida como consequência do estresse social produzido pela ausência de acesso a meios institucionais, fator responsável pela anomia social. Tendo como ponto de partida o contexto da sociedade norte-americana da primeira metade do século passado, Merton argumentou que a classe social seria um fator gerador de delinquência porque pessoas mais pobres têm oportunidades significativamente menores de realizarem os valores de uma sociedade que enfatiza o sucesso econômico acima de tudo. Esses indivíduos estariam submetidos a um sentimento de frustração social constante por não terem acesso aos meios necessários para atingir os objetivos que eles almejam. 0 sentimento de frustração pessoal pode então ser responsável por certas reações, por modos de adaptação que a pessoa utiliza para resolver os problemas gerados pela exclusão. 0 indivíduo pode adotar uma postura conformista por meio da aceitação dos valores e também das formas de organização social, ele pode tentar inovar a situação na qual vive incorporando ideais, mas rejeitando 
as normas institucionais estabelecidas para o alcance deles, ele pode também rejeitar as metas culturais e os meios para o alcance delas e ele pode, quando há uma aderência aos objetivos sociais, embora ele saiba que eles não poderão ser alcançados (MERTON, 1972, p. 203-205).

Robert Agnew escreve na tradição de Merton, mas incorpora elementos importantes que procuram corrigir certos problemas postos pela teoria funcionalista, notoriamente a falta de base empírica para a alegada relação entre delinquência e processos sociais. Um ponto central do pensamento de Agnew é o conceito de strain (sentimento de frustração ou estresse emocional), termo que define as reações emocionais a situações ou condições sociais que denotam tratamento arbitrário e desvantajoso sofrido por um indivíduo. Se Merton associava as injúrias de classe como origem da delinquência, Agnew considera inúmeros outros elementos e enfatiza as reações emocionais negativas que eles podem produzir no comportamento dos indivíduos. Esse autor observa que as instituições públicas e privadas reproduzem padrões e consensos culturais que permitem a integração apenas daqueles que ocupam certas posições dentro das estruturas sociais. Os que estão em uma condição subordinada não possuem os mesmos meios para alcançarem ou para agirem de acordo com esses objetivos culturais. Esses mecanismos são dificultados ou fechados a membros de certos grupos, o que pode produzir comportamentos desviantes em muitos deles. Estamos diante de uma situação altamente problemática porque temos, de um lado, a impossibilidade de acesso aos meios institucionais necessários para o alcance de objetivos compartilhados e, de outro, a reprodução de uma cultura política supostamente baseada em ideais igualitários. Isso seria motivo de um sentimento constante de frustração porque o indivíduo percebe que a sociedade não valoriza as pessoas da mesma forma (MERTON, 1938, p. 672-678).

A história retratada no filme Moonlight mostra que a criminalidade pode ser produto de inúmeros fatores relacionados com a estrutura social na qual as pessoas vivem. Vemos que a pressão sofrida pelo personagem principal gira em torno de determinados aspectos de sua identidade, notoriamente a identidade racial, a identidade de gênero e também os problemas relacionados à pobreza. Agnew afirma que emoções negativas 
decorrem de pressões culturais que aumentam a possibilidade de uma pessoa se engajar em atividade criminosa. Isso seria uma resposta que o indivíduo encontra para aliviar ou reduzir frustrações causadas por opressões que podem assumir diversas formas. Entre elas estão, por exemplo, o estresse decorrente do sentimento de inferioridade causado pela reprodução de estereótipos negativos ou a dificuldade de acesso a meios institucionais necessários para a realização de objetivos pessoais (AGNEW, 1984, p. 219-225).

A frustração pessoal é um indicador possível de delinquência, principalmente quando outras formas de solução de conflitos não estão disponíveis para as pessoas, como, por exemplo, sistemas de suporte social. Fazendo referência a inúmeros estudos empíricos de psicologia cognitiva sobre a reação individual a variáveis que podem gerar a frustração pessoal, o autor argumenta que muitos adolescentes são pressionados a adotar condutas ilícitas em função de estados emocionais negativos, principalmente aqueles associados à raiva e emoções correlatas, resultado frequente das relações problemáticas que ele mantém com outras pessoas (AGNEW, 1992). Esses estados emocionais fazem com que o indivíduo se sinta pressionado a eliminar a situação causadora de frustração. A delinquência não é um resultado necessário dessas emoções, mas aparece como uma predição de que a pessoa poderá utilizar meios ilegítimos (segundo os padrões dominantes) para atingir objetivos por ela valorizados ou para eliminar ou se desvencilhar da fonte de emoções negativas (AGNEW, 1992, p. 48-49). A frustração pode ocorrer quando o indivíduo não consegue atingir objetivos positivos, quando estímulos positivos para o alcance de suas metas não existem ou são retirados ou ainda quando a pessoa está sob a influência de estímulos negativos (HOSKIN, 2013, p. 26).

Seguindo uma tese comum a outras teorias funcionalistas, Agnew assevera que o crime está relacionado com a distância entre os sentimentos derivados das expectativas de tratamento igualitário presente dentro de sociedades democráticas e os meios disponíveis para que elas sejam realizadas. Os indivíduos criam expectativas ancoradas em metas culturais compartilhadas; emoções negativas surgem das dificuldades que certos grupos possuem por não terem condições de atuar de acordo com 
essas referências. As relações negativas têm origem nas representações depreciativas presentes em diversas formações culturais, formações que se tornam obstáculos para o alcance de objetivos pessoais. Uma sociedade comprometida com valores igualitários deveria fornecer todos os meios necessários para as pessoas poderem florescer, o que não acontece em função das diversas clivagens presentes entre grupos sociais. A expectativa de que certas regras básicas de justiça serão observadas, desperta o sentimento de frustração ou de impotência quando as pessoas não podem reverter a situação de injustiça em que se encontram (AGNEW, 1992, p. 53-55). Os indivíduos enfrentam diferentes experiências que podem promover sentimentos de desgaste psicológico em função da distância entre as expectativas pessoais e o que é efetivamente realizado. Isso também pode ocorrer quando outros retiram ou ameaçam retirar estímulos positivos disponíveis. Além dessas possibilidades, experiências de discriminação podem instituir ou ameaçar instituir estímulos negativos a uma pessoa. Isso inclui, por exemplo, tratamento institucional discriminatório, representações negativas de certos grupos, relações negativas no ambiente familiar e escolar, agressões verbais e físicas. Essas possibilidades podem gerar atos criminosos porque os indivíduos sempre buscam eliminar experiências que podem ser ou são dolorosas (AGNEW, 2001). Agnew afirma que emoções negativas como ressentimento e raiva motivam o indivíduo a agir, estimulam o desejo do indivíduo por retaliação e vingança e diminuem a inibição de sentimentos agressivos. Assim, a raiva aumenta a vontade de uma pessoa tomar ações para corrigir a situação que ela considera injusta, o que pode incluir atos ilegais. A experiência de discriminação é uma fonte significativa de frustração, principalmente quando ela possui um caráter difuso, o que não permite a identificação de um responsável direto. A falta de um responsável pelo sofrimento do indivíduo faz com que ele possa desenvolver um sentimento generalizado de raiva, de impotência, de depressão (HOSKIN, 2013, p. 26). 


\section{IDENTIDADE E MORALIDADE NO PENSAMENTO DE ERIK ERIKSON}

Da mesma forma que as escolas funcionalistas da criminologia, a psicanálise rejeita teorias comportamentais centradas em determinações biológicas como explicações do comportamento humano. Os seres humanos são vistos nessa disciplina como seres de desejo e isso implica a necessidade de explicarmos suas ações a partir do espaço social qual a subjetividade humana se forma. A sociabilidade surge como uma referência importante para a análise do funcionamento do psiquismo porque o desejo e a identidade do indivíduo são elementos das relações intersubjetivas que ele estabelece ao longo de sua vida. A constituição do sujeito a partir de suas relações com o outro nos permite questionar teorias que procuram explicar o comportamento como um tipo de disposição natural. Por ser produto de uma história particular, o sujeito humano não pode ser reduzido a um produto de determinações naturais. A psicanálise está centrada na noção de pulsão, termo que designa uma força psíquica que busca satisfação em objetivos que não são previamente determinados. Esse fato faz com que a estruturação psíquica do indivíduo dependa dos processos decorrentes das relações identificatórias que ele desenvolve com as pessoas que lhes são mais próximas. Por esse motivo, a construção do sujeito humano depende das estruturas sociais nas quais ele está situado. Elas serão o parâmetro a partir dos quais o indivíduo poderá construir a si mesmo ao ser inserido em uma estrutura familiar. ${ }^{7}$

O tema da identidade ocupa um papel central dentro da psicanálise, embora apenas alguns de seus teóricos tenham oferecido uma sistematização desse conceito. Se dentro da filosofia esse conceito reflete o sentimento de continuidade da consciência ao longo da vida, na psicanálise ele indica uma série de mecanismos psicológicos, a partir dos quais o indivíduo pode construir uma percepção integrada de si mesmo. Ele engloba nesse campo do conhecimento uma série de processos baseados em relações projetivas que as pessoas estabelecem umas com as outras com as outras ao longo da vida, principalmente no período da infância. A formação da consciência individual compreende um processo de identificações, processo que designa a assimilação de uma característica do outro 
que se torna em maior ou menor grau um atributo pessoal, contribuindo então para a formação da nossa própria identidade. Assim, as relações identificatórias entre os seres humanos comprovam o caráter intersubjetivo da formação das estruturas mentais, motivo pelo qual psicanalistas dedicaram grande parte de suas pesquisas ao desenvolvimento moral e psíquico dos seres humanos. $^{8}$

A teoria psicanalítica freudiana enfatiza as relações libidinais no desenvolvimento psicológico. Freud parte do pressuposto de que a energia sexual é um componente central do funcionamento do psiquismo humano, sendo o meio que possibilita a criação de uma noção integrada da consciência corporal e mental. Como o contato da criança com o mundo acontece por meio de partes do corpo humano que adquirem importância no processo gradual de formação de um sentimento de unidade corpórea, elas são eroticamente investidas, motivo pelo qual esse processo adquire significação psicológica. Para Freud, os seres humanos não nascem com um sentimento de unidade corporal formado, nem com uma noção clara de individualidade psíquica. Isso é atingido a partir da erotização de diferentes partes do corpo humano, processo que possibilitará a formação de uma unidade corpórea por meio do investimento libidinal no corpo do sujeito como um todo. Mais relevante, esse mecanismo terá um papel central na formação do próprio ego, da noção que o indivíduo pode ter, mesmo ilusória, de uma unidade psicológica (FREUD, 1972, p. 177-206).

Erik Erikson não rejeita os elementos centrais da teoria sobre o papel da libido no desenvolvimento psíquico, entretanto, afirma que essas fases possuem também uma dimensão social particularmente relevante que determina a formação da identidade. 0 autor chama a atenção para o fato de que o processo de formação da identidade do ego está necessariamente marcado pela interação do indivíduo com o meio social, uma das razões pelas quais Erikson a enfatizará o tema da identidade no desenvolvimento psíquico dos indivíduos. As fases do desenvolvimento propostas por Freud acompanham a lógica da forma como o corpo humano amadurece. A região bucal possui relevância porque é a forma principal a partir da qual a criança se relaciona com o mundo nos primeiros meses de vida por causa da alimentação; a região anal adquire maior relevância em função da necessidade do controle dos esfíncteres, momento seguido 
pela fase genital, período no qual o investimento libidinal passa para os órgãos sexuais. Erikson afirma que essas fases são mais complexas porque não há apenas uma questão de investimento libidinal, mas sim uma série de conflitos que precisam ser resolvidos pelo sujeito humano, conflitos que envolvem não apenas um processo sucessivo de erotização do corpo humano, mas principalmente questões de caráter psicológico que implicam a interação da pessoa com o ambiente social. Ela será construída a partir das respostas que a criança dará ao ambiente social que a cerca. Em cada uma dessas fases estão presentes questões como a permanente construção da confiança pessoal ou o senso de iniciativa (WELCHMAN, 2001, p. 39-43).

Além de propor uma reformulação da dinâmica do desenvolvimento formulada por Freud, Erikson expande também o conceito de ego proposto por aquele autor ao identificar essa instância com a identidade. Ele afirma que o ego ocupa um lugar central no aparelho psíquico por causa do seu papel na construção da relação entre o indivíduo e a sociedade. Ao atribuir ao ego esse papel, Erikson enfatiza a importância da função do meio social na formação da identidade; assim as fases do desenvolvimento são momentos nos quais diversos aspectos da identidade do ego são formadas. 0 autor afirma que uma resposta adequada do meio social permite a aquisição de elementos importantes da formação do eu como as noções de continuidade e consistência da experiência pessoal. Condições negativas presentes no ambiente, no qual o indivíduo está inserido pode limitar uma solução adequada para os conflitos que marcam as diversas fases do desenvolvimento psíquico das pessoas (ERIKSON, 1972, p. 136 - 142).

Mas, quais são os problemas psicológicos pelos quais os indivíduos passam ao longo de suas vidas que determinarão a formação de um senso de identidade? Erikson aponta a existência de certos estágios de desenvolvimento, fases nas quais as pessoas enfrentam crises que terão uma função central no processo acima mencionado. As questões enfrentadas nelas cumprirão um papel relevante na fase seguinte, ocasiões nas quais o sujeito humano se depara com questões cada vez mais complexas. 0 primeiro desses estágios é marcado por uma série de desafios que estabelecem uma oposição entre dois opostos a confiança básica e a 
desconfiança básica. Está aqui presente o problema da afirmação de um senso de confiança em si mesmo e nas relações humanas tendo em vista a continuidade e regularidade das relações entre o indivíduo e o mundo que o cerca. A resposta do ambiente social às necessidades do infante permite que ele crie um sentimento de estabilidade pessoal em função das respostas adequadas às suas demandas. Quando essas condições estão ausentes, surge a frustração pessoal, fator que cria dificuldades significativas para a formação de um sentimento positivo da formação da identidade individual (ERIKSON, 1963, p. 247-251). 0 próximo estágio é marcado pelo conflito entre os sentimentos de autonomia e a vergonha. A criança está aqui no momento de aquisição do controle de suas funções corporais, momento marcado por uma oposição entre a capacidade de aquisição de autonomia pessoal e a frustração de não poder alcançar o controle sobre si mesma. Assim, a conquista dessa habilidade é acompanhada de um processo psicológico de afirmação da segurança de poder ter controle pessoal, sentimento que poderá ser prejudicado quando o ambiente social restringe as possibilidades da pessoa alcançar esse senso de autonomia. A dificuldade de se alcançar essa representação positiva de si próprio neste estágio pode fazer com que a pessoa sempre tenha dúvidas sobre suas capacidades (ERIKSON, 1972, p. 107-110).

A evolução das capacidades motoras e cognitivas da criança faz com que ela entre em outro estágio no qual estão presentes os conflitos gerados pela oposição entre iniciativa e a culpa. 0 controle da linguagem e uma maior capacidade motora faz com que a criança entre em uma fase na qual as atividades passam por um processo de planejamento mental que permite a ela explorar o mundo e seu lugar dentro dele. A iniciativa complementa o senso de autonomia da fase anterior ao colocar para o indivíduo um planejamento da relevância de suas ações. 0 sentimento de culpa presente nesse estágio pode surgir em função das dificuldades da pessoa em obter uma resposta adequada do seu meio ao exercício dessas habilidades, seja pelo desencorajamento, seja pela ausência de estímulos suficientes, seja pela culpabilização por suas tentativas fracassadas. $\mathrm{Na}$ fase seguinte de sua vida, a criança está diante dos dilemas postos entre o sentimento de indústria e de inferioridade. A criança está agora em uma fase da vida na qual o círculo de relações sociais se expande considera- 
velmente; as aptidões adquiridas nos momentos anteriores cumprirão um papel importante agora que será testada sua capacidade de sociabilidade para além do círculo familiar. Assim, o senso de confiança básica e de indústria guiarão a ação daqueles indivíduos que obtiveram uma resposta adequada do ambiente que os cerca; os que não tiveram essa possibilidade desenvolverão um senso de inferioridade ou de inadequação, o que dificultará o aparecimento do sentimento de que elas estão aptas a se socializar e a cooperar com os outros de forma competente (ERIKSON, 1963, p. 255-261).

A fase da adolescência traz uma nova forma de exploração da identidade em função dos conflitos surgidos entre a identidade individual e a confusão de papeis. Para Erikson, o adolescente está agora em um momento no qual a noção de identidade pessoal não existe mais de forma simbiótica com a família; o indivíduo tem nesse período a noção de que ele é um ser que tem um futuro a ser construído por ele mesmo. Mais do que a soma das identificações que ele elaborou na infância, a identidade é parte de uma instância psíquica que reflete uma dimensão central do seu próprio ser. 0 ego terá agora a função de integrar todos os aspectos da identidade formados nas etapas anteriores, processo necessário para a formulação de um senso de identidade de caráter permanente. Os problemas que podem surgir nesse momento dizem respeito à dificuldade do adolescente em construir um senso de identidade que possa exercer essa função de integração da identidade. Característica dessa idade para Erikson é a questão da moratória moral. Esse termo descreve um estágio do desenvolvimento humano no qual as pessoas exploram diversas formas de identidade que poderão ou não ser parte contínua ou permanente da identidade do indivíduo. As ideologias sociais terão um papel importante nesse processo, pois elas apontam uma imagem do mundo a partir da qual ele poderá agir. Esse é um dos motivos pelos quais adolescentes são particularmente suscetíveis de serem seduzidos por certos grupos em função da necessidade de uma visão que permita a integração das várias formas de identificação que estruturam sua identidade de ego (ERIKSON, 1972, p. 127-136). Tal explicação justifica a chamada age-crime curve, aplicável a todas sociedades do ocidente e cujo pico é alcançado entre os 
15 e 19 anos e começa a declinar após os 20 anos (FARRINGTON, 1986; PIQUERO, FARRINGTON, BLUMSTEIN, 2007).

A fase adulta é marcada pela busca de relações pessoais baseadas na construção de intimidade emocional com outras pessoas. 0 que está, aqui, em jogo é a capacidade do indivíduo que em um período anterior estabeleceu um senso mais permanente de identidade de construir relações que possam perdurar durante a vida adulta. Se, por um lado, esse estágio está marcado pela busca de intimidade, essa busca poderá fracassar em função do isolamento, pela dificuldade em estabelecer intimidade emocional, o que acarretará o aparecimento de um sentimento de incompetência e isolamento individual. Outro conflito presente na maior parte da fase adulta ocorre em função da necessidade de harmonizar os conflitos decorrentes de produtividade contra a estagnação. Aqui, estamos diante da capacidade do indivíduo em tomar responsabilidade pelo seu bem-estar pessoal e também em ser um profissional competente. Do outro lado está a possibilidade do aparecimento de um sentimento de estagnação pessoal e o consequente empobrecimento da experiência pessoal, o que pode ter consequências para as gerações seguintes (ERIKSON, 1963, p. 263-269).

Os estágios de desenvolvimento humano propostos por Erikson nos permitem então relacionar alguns elementos importantes da noção de identidade, tema central de sua teoria. Relacionada a ela está a noção de identificações, o que dentro da teoria dele significa uma relação positiva ou negativa com as pessoas que podem ser referências confiáveis para o indivíduo. A identidade do ego é formada a partir de uma série de identificações que permitem a formação de uma unidade psicológica coerente para a pessoa (ERIKSON, 1963, p. 209-213). 0 autor afirma que os indivíduos que possuem uma identidade positiva porque conseguiram encontrar dentro do meio social as condições e oportunidades necessárias para a construção de um senso de bem-estar interior. A sociedade pode propiciar aos sujeitos as condições favoráveis para a superação dos conflitos que se sucedem ao longo do desenvolvimento moral pelo qual as pessoas passam. Isso possibilita a formação de uma consciência de uma identidade interior que é resultado de uma construção ativa do indivíduo ao longo da vida, construção que resulta da existência de rela- 
ções e condições estáveis. Ele pode construir uma sensação de confiança básica porque as condições sociais o reconhecem como um indivíduo capaz de desenvolver suas capacidades. Isso significa que, para Erikson, a identidade como um processo psicossocial no qual se relacionam as prescrições sociais de uma cultura comum e a identidade individual. 0 senso de identidade positiva existe quando a identidade é uma conquista do crescimento pessoal que reflete as formas de identidade disponíveis para os indivíduos. Podemos então depreender da teoria de Erikson que a construção de um senso positivo de identidade depende da existência de um repertório positivo de funções e lugares que o sujeito pode escolher para formar seu próprio destino (ERIKSON, 1966, p. 154-155; ERIKSON, 1963, p. 232-224).

Se, por um lado, a existência de referências adequadas permite a construção de afirmação de um senso positivo da identidade, a ausência delas terá como consequência a formação de uma identidade negativa. Esse termo descreve então aquelas identificações e prescrições sociais que são socialmente construídas como indesejáveis, lugares que supostamente designam a realidade de pessoas ou grupo de pessoas. Estamos, aqui, diante de um problema referente às questões de invisibilidade social de pessoas para as quais não são oferecidas as condições para a formação de um repertório de identidades positivo e suficientemente variado entre as quais os sujeitos podem escolher. Pelo contrário, os membros desses grupos não são pessoas que possuem escolhas; elas são marcadas por estereótipos prescritivos, ou seja, os lugares sociais que eles podem ocupar já estão socialmente determinados. Elas precisam então lutar contra essas falsas generalizações para que possam sobreviver psicologicamente. Essa é uma questão que aflige principalmente membros de grupos minoritários, pessoas que muitas vezes internalizam essas representações e prescrições negativas. Elas se tornam referências identificatórias que podem criar um sentimento perene de frustração pessoal, o que pode levar à delinquência (ERIKSON, 1963, p. 241-245).

Erikson argumenta que a possibilidade de formação de uma identidade pessoal positiva requer a existência de uma comunidade de pessoas que reproduzem valores que pode ser reconhecidos pelo indivíduo que está em processo de formação como elementos que devem ser integrados 
à sua experiência. Meras prescrições sociais não são meios suficientes para isso porque os indivíduos percebem que eles não servem como base para a construção ativa de processos de integração de si mesmo e, também, com a sociedade na qual ele vive. Portanto, as representações culturais que circulam dentro de uma sociedade carregam uma dupla função: servem como um fator de integração da personalidade e também permitem o comprometimento com a transmissão desses valores. A ausência dessa possibilidade faz com que as pessoas não desenvolvam um sentimento de autenticidade, mas sim uma sensação de que elas possuem uma identidade capturada: as chances que o indivíduo tem de se afirmar como um sujeito são limitadas em função de estigmas sociais que já determinam os lugares sociais que o indivíduo pode ocupar dentro da sociedade (ERIKSON, 1966, p. 157-158; ERISON, 1963, p. 244-246).

Para Erikson, a formação da identidade psicossocial está relacionada com a história em dois sentidos. Em primeiro lugar, ela é produto da configuração de fatos que ocorrem dentro de um contexto específico que é a experiência psicológica de um indivíduo concreto. As pessoas passam por uma série de crises ao longo da vida, crises que terão papel central na formação da identidade de um indivíduo particular. Em segundo lugar, argumenta Erikson, a identidade também está relacionada com as condições sociais presentes dentro de um momento histórico específico. As respostas que recebemos do meio no qual vivemos também depende da situação social de indivíduos que são sujeitos históricos. A possibilidade de uma resposta positiva que permite a solução de crises morais depende largamente da condição social das pessoas que são responsáveis pelo bem-estar das pessoas. Além das situações desses indivíduos, devemos também levar em consideração as formações culturais em um determinado momento histórico, formações que permitem ou impedem a construção de um repertório positivo de identidade. Assim, a exclusão social de certos grupos impossibilita a existência de condições ideais para o desenlace adequado das crises identitárias que membros de grupos minoritários passam ao longo da vida. Isso aumenta a possibilidade de uma reação contrária aos valores sociais, o que acaba sendo interpretado como um tipo de disposição natural das pessoas, processo que legitima ainda mais a exclusão (ERIKSON, 1966, p. 166). 
E, neste ponto, a proposta psicanalítica de Erikson encontra-se com a proposta criminológica de Agnew. Pois, se por um lado, as dificuldades materiais e sociais, fortalecidas pelo pertencimento a grupos minoritários e excluídos gerará no sujeito o sentimento de impotência e injustiça que o levará ao estresse e às emoções negativas e, consequentemente ao caminho da criminalidade (Agnew); por outro lado, faltará estrutura emocional e psíquica e este sujeito para qualquer destino diferente, pois, do pondo de vista psicológico, a criminalidade é o seu único destino nesta sociedade (Erikson), tal como o foi para Chiron. Tais condições negativas, tanto do ponto de vista psicológico, quanto do ponto de vista social, são reforçadas quando o sujeito masculino ainda tem que lidar com o problema da sexualidade, pois é uma segunda forma de discriminação e exclusão dentro de um ambiente que já é discriminado e excludente.

\section{DISCRIMINAÇÃO INTERSECCIONAL E DISCRIMINAÇÃO ESTRUTURAL}

Os sentimentos de frustração pessoal, que podem ser responsáveis pela delinquência, são produto de experiências sociais negativas, muitas vezes, decorrentes de práticas discriminatórias. Por esse motivo, uma compreensão adequada dos temas que estamos analisando nesse texto depende, também, de um exame de alguns processos de discriminação responsáveis pela marginalização de certos grupos e também de minorias que existem dentro deles. 0 termo discriminação tem um sentido bastante claro dentro dos estudos jurídicos: o tratamento intencional e arbitrário de uma pessoa por outra, tratamento baseado em um critério não permitido pela legislação. Isso acontece em função de julgamentos morais negativos presentes dentro da sociedade, sendo que eles são produto de estereótipos sobre membros desses grupos. Então, o que chamamos de "discriminação direta" está fundamentada no pressuposto de que há uma relação hierárquica entre o que discrimina e o que é discriminado. Ela viola o preceito de igualdade, preceito constitucional que requer o tratamento igualitário entre pessoas que estão similarmente situadas. A igualdade possui um caráter comparativo e isso significa que as pessoas 
devem ser tratadas da mesma forma se estão na mesma situação jurídica ou se possuem um mesmo traço. Assim, os indivíduos são sempre comparados a partir de um determinado vetor, vetor este que cria uma exigência de tratamento igualitário. Essa forma de tratamento arbitrário tem como base a premissa de que a discriminação tem um aspecto individual. Ela acontece nas interações entre indivíduos e é cometida por pessoas que desconsideram o comprometimento social com o tratamento igualitário (MOREIRA, 2017, p. 25-37).

Em tempos recentes, alguns pesquisadores formularam outra teoria de discriminação baseada no fato de que alguns grupos de pessoas não são discriminadas a partir de um único vetor de tratamento diferenciado. As pessoas podem sofrer desvantagens sociais sistemáticas em função do pertencimento a mais de um grupo minoritário, o que as situa na convergência de discriminações. Embora elas pertençam a minorias em relação aos grupos sociais dominantes, elas também estão em uma relação de desvantagem dentro das minorias das quais elas fazem parte. Problemas de discriminação que afetam o grupo são articulados entre seus membros, mas as questões relativas à experiência específica desses membros minoritários permanecem invisíveis. Pessoas que são negras e homossexuais estão em uma situação difícil de ser modificada por se encontrarem em uma situação de interseção de exclusões. Elas são discriminadas por membros do grupo racial dominante por serem negras, mas também são marginalizadas dentro da comunidade negra em função da orientação sexual. Assim, a situação dessas pessoas é estruturalmente distinta da dos outros membros do grupo porque são discriminados por mais de um vetor de exclusão social. Estudos mais recentes, seguindo a linha crítica proposta pelos autores da interseccionalidade, afirmaram que mulheres negras não são os únicos sujeitos que podem ser caracterizados como minorias dentro de minorias A marginalização decorre da operação conjunta de diferentes sistemas de opressão baseados em outras categorias como a classe e a sexualidade. Isso significa que as pessoas estão situadas de forma distinta dentro dos vários regimes hierárquicos, o que torna impossível conceber a realidade social a partir do pressuposto de que todos os indivíduos possuem uma experiência social homogênea (HUTCHINSON, 1999). 
Os estudos sobre teorias de discriminação levaram os autores a abandonar a concepção desse tópico como um mero comportamento individual motivado por estereótipos negativos. Muitas pesquisas nessa área demonstram que a discriminação tem um aspecto coletivo porque é praticada por diferentes indivíduos no espaço público e no espaço privado. Ela também possui uma clara dimensão institucional, estando presente na cultura e nas práticas de diversas organizações. Estereótipos motivam o comportamento das pessoas nas interações privadas, mas, também, enquanto representantes de instituições nas quais atuam. Além de poderem agir de forma discriminatória, os membros dos grupos sociais dominantes podem criar ou conformar as regras de funcionamento de instituições públicas e privadas para que elas operem de acordo com seus interesses. Isso significa que a discriminação contra minorias possui também um caráter sistêmico porque ela está presente nas diversas instituições sociais, organizações que atuam de forma integrada no processo de exclusão. 0 funcionamento desses mecanismos impede o acesso a oportunidades aos membros de minorias em uma série de situações ao longo do tempo e em diversas áreas da vida pessoal, o que contribui para a formação de processos de estratificação de caráter durável (TILLY, 1998; MASSEY, 2007).

Sistemas de opressão como o racismo e a homofobia podem ser então classificados como um tipo de discriminação estrutural porque designam uma prática social que gera a estratificação racial em função da convergência de diferentes formas de exclusão que afetam diversas áreas da vida pessoal. Os autores que formularam o conceito de discriminação estrutural afastam-se de uma compreensão dele como um ato de natureza psicológica e individual; eles enfatizam os processos sociais que convergem para gerar diferentes formas de desvantagens materiais, mecanismos que operam independentemente da vontade de pessoas. Não podemos esquecer, então, que tipos de discriminação como o racismo não é uma mera percepção inadequada da realidade, mas um sistema de opressão. Ele impede que membros de minorias raciais possam ser socialmente integrados, fator responsável pela reprodução de padrões de estratificação social. 0 racismo estrutural produz o problema apontado por Erik Erikson: essa prática social informa o funcionamento das institui- 
ções sociais, o que restringe o repertório de identidades disponíveis aos indivíduos. A reprodução do racismo no funcionamento das instituições legitima processos discriminatórios que impedem o acesso de minorias a oportunidades. Mais do que isso, esses estereótipos determinam os lugares sociais que membros de minorias raciais podem ocupar dentro da sociedade, o que reduz as opções disponíveis para minorias poderem construir o próprio futuro. Os estereótipos raciais cumprem um papel central na formação da identidade negativa de certos grupos sociais: eles fazem circular uma série de representações negativas sobre minorias, o que impede a construção de um senso pessoal de valor por parte dessas pessoas, situação que também vai ao encontro da teoria de Agnew, a partir da ideia de que a discriminação estrutural faz com que os membros dos grupos discriminados vivenciem, o tempo todo, emoções negativas e estresse, seja pela desvantagem em que se encontram numa sociedade que prega a "igualdade", seja pela sua própria identificação como fonte de perigo e criminalidade, sendo objeto preferencial das instâncias de controle social.

\section{A CONSTRUÇÃO SOCIAL DA MASCULINIDADE}

Certa tradição da psicologia do gênero sempre partiu do pressuposto de que nós podemos identificar, com clareza, os traços da masculinidade e da feminilidade porque eles são elementos naturais do comportamento de homens e mulheres. Ela está centrada na ideia de que essas características podem ser claramente apontadas na atuação dos sexos. Eles e elas teriam então personalidades sexuais, cujas diferenças correspondem às distinções presentes na realidade biológica (CONNEL, 1987, p. 167). Da mesma forma que a articulação entre raça e poder possibilita a compreensão da natureza discursiva das práticas responsáveis pela reprodução da estratificação racial, a relação entre gênero e poder também oferece elementos para examinarmos a natureza discursiva da masculinidade e da feminilidade, identidades que estruturam diversas formas de hierarquias sexuais. Muitos pensam que a masculinidade é uma forma de comportamento natural, mas essa percepção encobre suas várias funções 
culturais e políticas. Em primeiro lugar, devemos ter em mente que ela é uma forma de identidade a qual homens e mulheres precisam se ajustar para que possam obter respeitabilidade social. Tendo em vista sua natureza prescritiva que tem a função de determinar as funções sociais dos indivíduos, padrões de comportamento, a masculinidade deve ser entendida como um tipo de identidade hegemônica, como um tipo de governança pessoal e social que determina a forma como as pessoas devem se apresentar e se portar nas diferentes esferas de suas vidas. Ela estrutura várias relações de poder entre os sexos, mas, também, entre os próprios homens porque é uma forma de identidade que também estrutura os lugares sociais que homens de diversas origens podem ocupar dentro da sociedade (BOURDIEU, 2002).

A abordagem da identidade de gênero como algo instituído a partir de relações de poder teve início com a crítica feminista a algumas premissas do funcionamento do sistema patriarcal, entre elas a ideologia que baseava o comportamento e o destino feminino em designações de caráter biológico. Essas autoras enfatizavam a natureza social do gênero, ponto de partida para a construção de uma crítica da noção de papéis sexuais naturais entre homens e mulheres (BUTTLER, 1990; MARTIN, 2004; WEST, 1998). Os estudos feministas sobre o gênero como construção social possibilitaram o questionamento da natureza social da masculinidade como elemento central da cultura heteronormativa. Aqueles que denunciavam a opressão contra homossexuais diziam que a associação entre masculinidade e heterossexualidade legitima uma ordem social baseada na noção da superioridade moral de homens heterossexuais. Da mesma forma, as relações entre poder e diferença estavam no centro da crítica dirigida a certas ideologias que associavam a masculinidade à classe social, articulação que permitia a afirmação de que apenas homens de certas faixas sociais expressavam o ideal pressuposto por essa forma de identidade. Argumentação similar aparece nos estudos sobre raça e gênero, campo de investigação que indica a masculinidade como forma de identidade ideal, representação associada aos membros do grupo racial dominante porque ela também é uma forma de comportamento moral que nem todos os homens podem expressar. Estudos psicológicos também começaram a criticar concepções de "papel sexual masculino", 
construção que passa a ser vista como um meio de legitimar a opressão sexual por meio da reprodução de estereótipos de gênero, fator também presente nas diversas formas de discriminação dirigida a homossexuais (CONNEL; MESSERSCHMIDT, 2005, p. 829-832).

A crítica elaborada a partir desses diferentes movimentos culturais permitiu a formulação de uma nova abordagem fundada na centralidade do poder na formação da noção de masculinidade. Alguns elementos precisam ser mencionados para podermos ter uma compreensão adequada desse termo. A masculinidade possui um caráter relacional porque adquire sentido em oposição a outras categorias sociais. Em primeiro lugar, ela aparece como a antítese da feminilidade porque designa elementos que estão culturalmente representados como traços naturais de pessoas do sexo masculino. A masculinidade existe em sociedades que tratam homens e mulheres como grupos que possuem características naturais e opostas. Essa forma de identidade atua dentro de uma estrutura hierárquica entre os sexos, determinando a construção da identidade pessoal de homens e mulheres, lugares que não se referem à realidade biológica, mas às normas culturais que são reproduzidas pelo discurso jurídico (CONNEL; MESSERSCHMIDT, 2005, p. 829-832). Designa padrões de comportamentos que expressam formas de ser típicas dos sexos. Embora essa noção tenha caráter essencialista, ela designa certas qualidades que transcendem a realidade corpórea daquele que a exibe. A masculinidade é um padrão cultural que pode ser exibido também por mulheres, evidência de um comportamento anormal.

Seguindo teses de Michel Foucault, muitos atores afirmam que a masculinidade é um tipo de prescrição social que determina o que homens devem ser, como eles devem se comportar em várias situações. A masculinidade opera como um regime social de controle da sexualidade porque estabelece parâmetros que devem ser seguidos por todos os homens. Ela adquire importância central no processo de socialização das pessoas do sexo masculino ao determinar os parâmetros a partir dos quais elas deverão se apresentar socialmente. Assim, a caracterização da heterossexualidade como expressão natural da sexualidade humana cumpre funções importantes no funcionamento da homofobia. A homofobia implica um esforço incessante de preservação de controles culturais que 
têm a função de disciplinar os corpos humanos nos diferentes espaços sociais. A normalização dos indivíduos tem um objetivo: a exclusão de atos sexuais e formas de apresentação social contrários às expectativas criadas em relação aos gêneros. Essa categorização possibilita a construção da heterossexualidade como uma forma de identidade pessoal que será um princípio de classificação de todas as outras. Ao adquirir ascendência cultural, as regras da heterossexualidade passam a ser um meio pelo qual os corpos humanos são adestrados para desempenhar seus papéis supostamente naturais. As expectativas culturais legitimam controles sociais baseados em uma cultura do insulto. Todos os que não se adequam estritamente às prescrições sociais em relação à sexualidade serão páreas sociais, situação que legitima uma série de ofensas pessoais dirigidas aos que não se adequam ao que é esperado da sua performance como membro de um sexo particular. Esse é o motivo pelo qual crianças e adolescentes homossexuais e heterossexuais são constantemente vigiados e forçados a seguir um roteiro que procura garantir a conformação sexual (PRADO; JUNQUEIRA, 2011, p. 59-61).

A masculinidade é uma construção cultural que legitima uma série de relações hierárquicas entre homens e mulheres, mas também entre os próprios homens. É importante reconhecermos que ela atua ao lado de outras categorias sociais que legitimam hierarquias de poder. Isso significa que devemos falar em diversas formas de masculinidades porque ela expressa ideais que nem todos os homens podem alcançar porque esse grupo social também possui uma divisão interna de acordo com categorias como raça e classe. Devemos então falar de uma masculinidade hegemônica em relação a masculinidades subordinadas. Isso significa que a masculinidade exibida por homens de classe social inferior não pode se afirmar como uma identidade universal porque ela não corresponde à representação daqueles que regulam as estruturas de poder. A masculinidade exibida por homossexuais não pode ter o mesmo status que a masculinidade exibida por heterossexuais porque a homossexualidade é um tipo de identidade subordinada. 0 mesmo processo acontece quando examinamos a questão racial porque a negritude não pode ser uma identidade que pode expressar os ideais morais associados aos membros da raça branca (MOREIRA, 2016; MORREL, SWART, 2005). 
Se a tese de que há uma relação necessária entre gênero e poder é correta, não podemos deixar de considerar as variações que existem entre homens e entre mulheres. Elas são produto da associação com outras formas de dominação, sendo que a raça e classe determinam como as pessoas vivenciam o gênero (HOLTER, 2005). Dessa forma, a masculinidade, embora seja uma forma de identidade prescritiva, é um meio para a expressão apenas parcial de uma identidade positiva de homens negros. Na verdade, as representações sociais da masculinidade negra podem ser classificadas como expressões de identidade de caráter negativo porque enfatiza a relação entre a masculinidade e a agressividade, fato que está presente nas várias produções culturais que retratam homens negros como naturalmente inclinado à criminalidade. A compreensão da relevância social da masculinidade negra depende então de sua associação com diversos tipos de estereótipos raciais sobre homens negros. Ela é produzida então dentro de um contexto social específico: de um lado ela é um contraponto à masculinidade hegemônica associada aos membros do grupo racial dominante. Ela possui um caráter negativo porque não surge como algo conquistado pelo próprio grupo, mas é produto da convergência de diversas formas de dominação presente no mundo cultural (HARPER, 1996; HOOKS, 2014). A masculinidade negra é um tipo de identidade descritiva porque afirma supostas características dos membros desse grupo; ela também possui um caráter prescritivo porque determina as formas como membros desse grupo devem expressar sua identidade de gênero. É importante notar então que a masculinidade negra é produto da associação de diferentes sistemas de exclusão que determinam o lugar que eles podem ocupar dentro da sociedade: o racismo, o classismo, o patriarcalismo e a homofobia (BENITEZ, 2006; CARBADO, 2000).

\section{O CONCEITO DE REPERTÓRIO IDENTIFICATÓRIO}

Para melhor compreendermos as relações entre masculinidade e criminalidade, devemos sistematizar agora as dimensões do conceito de repertório identificatório, noção que será utilizada para explicar as 
causas da criminalidade contra e entre membros de duplas minorias. A primeira está relacionada com a dinâmica cultural que legitima a violência contra esses indivíduos, dinâmica baseada nas relações entre identidades hegemônicas e identidades subordinadas. Essa relação hierárquica determina quais são as identidades que podem ter expressão no espaço público, o que o torna uma dimensão normatizada. A segunda parte da premissa de que a experiência de membros de grupos minoritários é determinada pela convergência de diferentes formas de opressão, o que restringe as possibilidades de acesso aos meios institucionais para o alcance de objetivos pessoais. Por fim, a terceira está relacionada com identificação das condições culturais e materiais que podem fomentar a inclusão ou promover a exclusão de grupos minoritários.

Como um aparato teórico que procura explicar as possíveis causas da criminalidade contra e por membros de duplas minorias, a noção de repertório identificatório está relacionada com a posição que esses indivíduos ocupam dentro dos vários sistemas hierárquicos. Por um lado, ela adquire sentido dentro da dinâmica da criação de significados e identidades culturais dentro de uma sociedade. 0 status de um grupo decorre do nível de prestígio social de seus membros, produto de atribuições negativas ou positivas decorrentes de diversas construções culturais. Elas desempenham uma função importante: a legitimação das formas como as pessoas se relacionam no espaço público e no espaço privado, os parâmetros que elas utilizam para construir referências identitárias e também os valores que influenciam o funcionamento das instituições sociais. ${ }^{9}$ Sentidos culturais determinam a criação de um senso de identidade individual e coletiva que adquire coerência em oposição a de outros grupos. Eles se tornam cultural e politicamente prevalentes em função do potencial delas em manter a estrutura de relações de poder (BLUMER, 1958). Conflitos sociais surgem porque regras culturais que legitimam sistemas hierárquicos são sempre contestadas; grupos minoritários questionam sua legitimidade de forma a poder conseguir maior inclusão social (BALKIN, 1997). Essa demanda implica a busca por maior visibilidade social e também a transformação dos sentidos culturais. A violência contra membros de grupos minoritários pode decorrer, por exemplo, por 
causa da violação de regras culturais de gênero que estabelecem lugares e prescrições comportamentais para homens e mulheres (LAW, 1988).

0 conceito de repertório identificatório incorpora elementos importantes de escolas criminológicas que deslocaram a explicação da criminalidade do indivíduo para as estruturas sociais. Observamos, anteriormente, que, para Agnew, a delinquência está associada a uma série de fatores geradores de frustração pessoal, fatores que também estão associados às representações de minorias. Elas podem impedir o alcance de objetivos pessoais por legitimarem mecanismos de exclusão baseados em identidades particulares. Os indivíduos possuem diversas formas de identidades; eles ocupam diferentes posições dentro dos sistemas de hierarquia, motivo pelo qual as disfunções do funcionamento dos sistemas sociais não podem ser atribuídas a uma única causa. Essas diferentes posições são causa de diversas formas de subordinação social que podem impedir a construção de uma identidade positiva pelos indivíduos. Mais do que isso, eles não permitem que eles tenham acesso aos meios necessários para a realização do que eles consideram ser objetivos sociais relevantes. Portanto, os lugares sociais que eles ocupam atuam como verdadeiras prescrições, como limites ao que os indivíduos podem aspirar (CARBADO; GULATI, 1999).

Tendo em vista o que argumentamos no parágrafo anterior, essa dimensão cultural do conceito de repertório identificatório nos permite identificar os conflitos surgidos entre as identidades que possuem um caráter hegemônico e aquelas que são construídas como identidades marginais. A análise que Erik Erikson realiza sobre os mecanismos responsáveis pela reprodução de identidades positivas e negativas expressam o conflito entre identidades hegemônicas e aquelas que são subordinadas. A invisibilidade é uma das características mais importantes das identidades hegemônicas: elas se tornam a referência a partir da qual todas as outras serão julgadas; elas adquirem um status normativo, razão pela qual muitas outras são sempre classificadas como desviantes ou inferiores (CARABINE, 1996; CARBADO, 2000; WARD, 2008; WARE, 2000). Heterossexualidade e masculinidade podem ser vistas como exemplos de identidades hegemônicas que influenciam amplamente o funcionamento das instituições sociais, determinando as chances que as 
pessoas terão de conseguir acesso aos meios adequados para a realização dos seus interesses. Como observa David Owen, uma identidade hegemônica possui certas propriedades funcionais destinadas a reproduzir os interesses dos grupos majoritários. Entre elas está a formação de uma interpretação do mundo que reflete os pontos de vista dos que estão em posições superiores nas diversas hierarquias de poder, elas designam os lugares que as pessoas ocupam dentro dessas hierarquias, elas são normalizadas por estarem associadas com o funcionamento natural da sociedade e elas representam posições de poder e não traços biológicos como vários autores sociais ainda defendem. Além disso, não podemos deixar de reconhecer que uma propriedade funcional dessas identidades hegemônicas é a violência: elas são formas de legitimação da exclusão social daqueles tidos como subalternos (OWEN, 2007, p. 203-209).

Uma vez examinada a dimensão cultural do conceito de repertório identificatório, devemos partir para a concepção de sujeito nele presente. A direção aberta nos parágrafos anteriores sugere que o sujeito humano deve ser pensado como um efeito das estruturas de sentidos sociais nas quais ele está inserido; seu comportamento adquire significação dentro desse horizonte e não a partir de disposições naturais. Motivos para a violência contra e por membros de minorias raciais e sexuais são criados dentro de sistemas hierárquicos que determinam as identidades que os indivíduos ocupam e as identidades que podem ter expressão no espaço social. É o caso da masculinidade, um conjunto de significações culturais que criam os parâmetros a partir dos quais identidades pessoais e coletivas são criadas. Mais do que isso, dela dependerá também a formação da maneira como os indivíduos devem compreender o funcionamento da sociedade. Se, por um lado, a masculinidade é um tipo de performance social, por outro, ela produz sentidos que servem como parâmetro para a atuação e interpretação das relações sociais. Seguindo a sugestão de Robert Blumer, podemos entender a masculinidade como uma referência de criação de um sentido de identidade de grupo, o que também determina a construção de seu oposto. Assim, ao falarmos sobre repertório identificatório, devemos estar atentos ao fato que não podemos afirmar a existência de um consenso sobre o ilícito porque as regulações sobre as relações entre grupos decorrem da possibilidade dos grupos domi- 
nantes estabelecerem sentidos culturais. Mais uma vez, estamos então diante de uma dinâmica entre identidades hegemônicas e identidades subordinadas (BLUMER, 1958).

Queremos dizer então que as diversas formas de exclusão, às quais os sujeitos estão expostos, não permitem que eles tenham acesso a um repertório social que possibilite a escolha do próprio futuro porque a possibilidade de plena ação autônoma está sempre restringida pelas estruturas sociais. Portanto, o conceito de repertório identificatório, proposto por Erik Erikson nas suas análises sobre identidade, tem um papel relevante para compreendermos processos que podem levar à delinquência. A possibilidade de formação de uma identidade positiva decorre da existência de oportunidades sociais e de uma cultura que afirma a igualdade moral de todos os membros da comunidade política, opção de caráter restrito em um sistema social marcado pelo conflito entre identidades hegemônicas e subordinadas. Isso significa que aqueles que não têm acesso a essa oportunidade poderão desenvolver uma identidade negativa, porque a sociedade já determina quais são os lugares dessas pessoas. Tais prescrições legitimam processos discriminatórios que restringem a possibilidade dos membros de certos grupos poderem seguir uma direção baseada nas escolhas socialmente abertas a eles. Ao mesmo tempo que a sociedade espera uma performance desses indivíduos em função das limitações e prescrições que ela mesma estabelece, ela também encobre os mecanismos que restringem as oportunidades de integração social. Como afirmar Agnew, a delinquência pode surgir quando pessoas estão imersas em relações sociais negativas que impedem a existência ou retiram estímulos positivos. A restrição do repertório identificatório, aliada à ausência de outras formas de solução de conflitos, pode então levar membros de duplas minorias à marginalidade.

A dimensão antropológica do conceito de repertório identificatório adquire maior sentido quando levamos em consideração que muitos sujeitos estão apenas submetidos a diferentes sistemas hierárquicos. Muitos sofrem as consequências da intersecção de discriminações por pertencerem a mais de um grupo minoritário, o que aumenta a possibilidade que essas pessoas tenham suas identidades capturadas Isso aumenta o sentimento de frustração pessoal por dificultar o alcance de 
inclusão social. A restrição de identidades positivas aumenta os níveis de estresse mental, possível fator gerador de frustração pessoal e da delinquência. Por ser uma forma de prescrição social que se manifesta por meio da exigência de uma performance de gênero, a masculinidade impõe limites para a atuação e expressão social dos indivíduos do sexo masculino. Para os que são homossexuais ou socialmente percebidos como homossexuais, ela aparece como uma aspiração que não pode ser alcançada, o que gera a frustração pessoal. Para os que são heterossexuais, a masculinidade atua muitas vezes como um mecanismo que frequentemente leva homens a agirem de forma violenta contra os que são minorias sexuais. Essa pressão social é ainda maior entre aqueles que são duplas minorias porque a masculinidade torna-se um ideal ainda mais distante (HOOKS, 2003, p. 47-66).

A dimensão material do conceito de repertório identificatório deve ser pensada como um princípio explicativo e também como uma direção para ações estatais. Por um lado, esse conceito nos permite entender aspectos sobre a dinâmica da produção social do crime que ainda são obscuros. Ele nos convida a entender a natureza multifatorial na qual estão envolvidas ideologias e práticas relacionadas com as condições sociais, a partir das quais identidades sociais são criadas e reproduzidas. Partimos da premissa de que a identidade não é uma mera construção pessoal, mas fundamentalmente o produto da interação entre o sujeito e o mundo que o cerca. Assim, a criminalidade pode surgir da falta de oportunidades sociais oferecidas aos membros da comunidade política, fato que está relacionado com a frustração causada pela constante circulação de estereótipos descritivos e prescritivos que determinam os lugares que as pessoas podem ocupar. A noção que estamos analisando também deve ser entendida como um princípio para a ação das instituições governamentais porque nos permite diagnosticar as formas a partir das quais diferentes sistemas de opressão operam para produzir a exclusão. A prevenção da criminalidade pode ser possível na medida em que ações estatais promovam a igualdade de status cultural e a igualdade de status material. Implementar políticas públicas capazes de eliminar representações negativas sobre grupos sociais podem promover uma transformação da condição material na qual eles vivem, condição 
necessária para a prevenção da criminalidade. Assim, se de um lado o conceito de repertório identificatório nos auxilia a identificar os meios pelos quais a reprodução de estereótipos e desvantagem material restringem as oportunidades sociais das pessoas permitindo a criação de uma identidade negativa que pode conduzir ao crime; de outro, ele permite atuar para a construção de uma sociedade mais democrática ao instituir parâmetros para a criação de mecanismos que fomentam a autonomia humana (NELSON, 2009; LOURY, 2002).

Em resumo, o conceito de repertório identificatório designa três fatores importantes para entendermos as possíveis relações entre identidade e criminalidade. Primeiro, ele está fundamentado na noção de que um processo de socialização capaz de promover a integração social oferece meios para que os indivíduos possam construir um senso positivo de identidade. Segundo, ele parte do pressuposto de que a integração social ocorre quando diferentes indivíduos podem buscar objetivos legítimos, o que depende da existência de uma cultura pública que permite a inclusão dos diferentes grupos sociais. Terceiro, ele afirma que as razões da criminalidade não estão nas supostas disposições naturais dos indivíduos, mas nas falhas estruturais presentes dentro dos sistemas sociais, sistemas cuja lógica reproduz mecanismos discriminatórios. A constante reprodução de identidades hegemônicas restringe a possibilidade da existência de referenciais positivos para grupos minoritários, o que pode geral a delinquência.

\section{MASCULINIDADE E CRIMINALIDADE EM MOONLIGHT}

O filme Moonlight nos conta a história Chiron, narrativa centrada em três momentos da vida de um homem negro. A primeira parte fala de sua infância, momento marcado por constantes agressões físicas. Sua compleição corporal e seu temor de crianças maiores motivam a agressividade de outros meninos que se deleitam com as agressões dirigidas a esse personagem que tem o apelido de Little (pequeno). Seu comportamento, dentro de um meio social no qual masculinidade e agressividade estão fortemente ligados, faz com que os outros também 
questionem sua sexualidade, questão que surge principalmente porque ele não expressa a agressividade exigida por seu meio social. Little tem poucas referências afetivas positivas dentro de seu meio. Seus colegas são uma ameaça constante e sua mãe não lhe dá muita atenção porque ela está sempre à procura de renda para sustentar sua drogadicção. Seu filho é um empecilho e ela sempre demonstra alto grau de agressividade em relação a ele.

Little encontra uma referência positiva no homem que controla o tráfico de drogas ilícitas no bairro no qual mora, a única pessoa que parece se preocupar com ele. Juan cumpre um papel importante na vida presente e futura de Little, embora ele também seja uma fonte de decepção. Juan surge como uma referência de afeto e também como modelo de masculinidade para o menino negro que só conhece violência e rejeição em quase todas as suas interações sociais. Juan permite que ele construa um pouco de confiança, ele se torna uma referência positiva, embora também, indiretamente, cause dor ao menino por estar envolvido em uma atividade que prejudica ainda mais a relação com sua mãe. Little ainda tem no seu colega Kevin outra referência importante, mas ambígua. Ele é uma das pessoas que também o pressiona a afirmar sua masculinidade por meio da agressividade, sem ter muita certeza do possível significado disso.

A segunda parte do filme nos fala da adolescência do personagem que agora atende pelo apelido de Black, forma pela qual ele é tratado pelo seu amigo Kevin. Não vemos muitas modificações na vida cotidiana de Black. Ele ainda sofre as consequências da desestruturação familiar, ele ainda é constantemente ameaçado por outros adolescentes do bairro que estão sempre dispostos a afirmar a masculinidade por meio da agressão física e do assédio moral de outros meninos negros. Juan desapareceu, mais uma vítima da violência associada ao tráfico. Porém, sua namorada, Teresa, ainda continua sendo uma fonte importante de afeto. Black é um adolescente e a sexualidade é também agora uma questão importante, mas o exercício dela encontra obstáculos em uma realidade na qual homens mais assertivos são os que mais conseguem ter acesso a parceiros ou parceiras sexuais. Seu colega Kevin, mais uma vez, é a pessoa que surge como uma referência afetiva positiva e negativa. Ele tem sua iniciação sexual com esse adolescente que também será o motivo pelo 
qual sua vida acaba sendo ainda mais desestabilizada. Kevin agride Black para satisfazer a pressão de outros adolescentes e ele, revoltado com as constantes humilhações e agressões que sofria, agride um dos seus agressores com uma cadeira, o que o leva à detenção por alguns anos.

$\mathrm{Na}$ terceira parte do filme, vemos um personagem que agora atende pelo nome de Chiron. Esse homem adulto não é mais um indivíduo frágil sempre temeroso de ser vítima de violência. Ele agora incorpora um personagem que expressa uma virilidade ideal: elementos da masculinidade hegemônica foram internalizados e passam a motivar seu comportamento. Seu corpo atlético e sua postura agressiva garantem a ascendência necessária para seu trabalho como traficante, atividade que ele dificilmente poderia desempenhar sem essas características. 0 relacionamento com sua mãe ainda é fonte de imensa frustração pessoal, mesmo que ela agora esteja internada em um centro para recuperação. Porém, tal fato não é suficiente para eliminar todo o sofrimento que Chiron sofreu ao longo da vida. Kevin novamente aparece na vida de Chiron. Ele também passou algum tempo na prisão, mas não está mais envolvido com o tráfico porque tem um filho e pretende ser uma referência positiva para a criança. Chiron se encontra com Kevin, a única pessoa com a qual ele compartilhou um momento de intimidade afetiva.

\section{CHIRON E O ENIGMA DA MASCULINIDADE HEGEMÔNICA}

As teorias acima mencionadas conduzirão nossa análise de três questões postas para o personagem central do filme Moonlight, sendo que elas são importantes para entendermos as relações entre masculinidade e criminalidade: o que é ser um homem? O que é ser um homem negro? 0 que um homem negro pode esperar? Argumentaremos que elas estruturam a narrativa do filme sob análise, sendo que o tema da masculinidade está presente em todas elas. Suas articulações com outros temas relacionados à identidade surgem como enigmas que o personagem do filme procura desvendar ao longo da vida, embora não tenha muitas chances de encontrar respostas baseadas em construções pessoais. A história de Chiron retrata a situação de centenas de milhares 
de jovens negros, cujas vidas são destruídas porque seus lugares sociais já são definidos desde o nascimento. Eles vivem em uma sociedade que os confina a uma situação de desigualdade permanente, sendo que esse tema está diretamente relacionado com as formas de identidades a partir das quais hierarquias sociais são construídas. ${ }^{10}$

A pergunta sobre os sentidos da masculinidade atravessam toda a narrativa do filme em discussão. Desde o início vemos indivíduos que operam a partir de construções sociais sobre atitudes masculinas, atitudes que decorrem de ideais institucionalizados que servem como parâmetros para seus atos. Os meninos que agridem Little atuam a partir de elementos sob os quais eles possuem pouca influência porque a masculinidade é um tipo de performance social imposta a todos eles. Mas, na realidade tratada em Moonlight, o tema da masculinidade não pode ser entendido fora do contexto da raça. Certos autores argumentam que a experiência do homem negro precisa ser vista a partir de um ponto de vista multidimensional em função das várias determinações de sua experiência social. Enfatizar a relação entre sexualidade, masculinidade e poder é então um elemento necessário para a análise da violência contra minorias dentro de minorias. 0 filme mostra um lado relevante da cultura patriarcal: homens são socializados a partir de referências bastante restritas, sendo que quaisquer distorções delas podem gerar a exclusão; a experiência masculina só pode fazer sentido dentro dessas construções. Por esse motivo, vemos o personagem sofrer várias formas de terrorismo psicológico ao longo do filme porque ele não corresponde às expectativas existentes dentro de uma cultura patriarcal. Chiron precisa descobrir os sentidos da masculinidade, um tipo de identidade que já possui um significado determinado e a qual ele precisa se ajustar. Esse tipo de identidade aparece para ele como uma necessidade de afirmação de assertividade e agressividade Da mesma forma que todos os outros homens, Chiron aprende que a masculinidade está necessariamente ligada à agressividade. Entretanto, a possibilidade de se afirmar como um homem perante as outras crianças está limitada por causa da sua compleição física, sinal de que ele possui uma masculinidade subordinada perante as outras crianças que são mais agressivas do que ele (THOMAS, 1996, p. 55-69). 
A correlação entre masculinidade e agressividade adquire uma conotação ainda mais relevante dentro da realidade social na qual esses personagens vivem. Muitos personagens do filme interpretam a homossexualidade como uma ameaça à masculinidade negra, construção que luta para conseguir lugar em uma realidade na qual a masculinidade ideal está associada a homens brancos (COLLINS, 2004, p. 174). Ela é ainda mais enfatizada porque todos se encontram em uma situação de vulnerabilidade social; todos parecem estar cientes que suas vidas são socialmente irrelevantes, motivo pelo qual a agressividade adquire importância como estratégia de sobrevivência. Os jovens negros presentes no filme estão conscientes de que a sociedade na qual vivem oferecem poucas oportunidades para que eles possam escolher seus próprios destinos. Diante desse repertório identificatório restringido pelas consequências do racismo estrutural, a masculinidade surge como um recurso simbólico que o indivíduo pode ter, um dos motivos pelos quais ela precisa ser enfatizada ao máximo. As possibilidades de prestígio dentro da sociedade estão reduzidas à chance de ter algum dinheiro derivado do tráfico, uma vez que trabalhos mais rentáveis não estão disponíveis a pessoas que estão em escolas de baixa qualidade.

Um grave problema aflige todos esses indivíduos. Embora procurem afirmar a masculinidade em todos os momentos, homens negros não são tipos sociais ideais. 0 filme mostra claramente a lógica a partir da qual essa forma de identidade social opera. Chiron não poderia compartilhar do respeito de outros homens negros porque ele não exibia os elementos característicos da masculinidade negra, um tipo de identidade que, naquele contexto, se expressa por meio de uma agressividade acentuada, característica que só pessoas heterossexuais podem ter. É curioso perceber que os outros garotos o chamam de homossexual, mas isso não parece estar ligado a um comportamento dele, mas, sim, porque ele não exibe o tipo de masculinidade que homens negros deveriam ter. Chiron não tem qualquer ideia do significado da palavra que designa homossexuais, grupo que não pode nunca ter o mesmo tipo de legitimidade que negros heterossexuais têm acesso. A presunção da homossexualidade do garoto decorre apenas do fato de que sua performance de gênero não corresponde ao ideal de comportamento 
esperado pelos membros do grupo daquele meio. Mesmo dentro desse grupo de pessoas excluídas, a masculinidade de Chiron aparece como uma forma de identidade subordinada porque é interpretada como sinal de fragilidade.

Os comportamentos delinquentes que percebemos no filme têm como pano de fundo os conflitos gerados pela expectativa de uma performance de gênero e a particularidade emocional dos personagens. Isso força Kevin a participar da agressão a Chiron, pessoa com a qual tinha compartilhado um momento de intimidade sexual dias antes. Terrel é um jovem que encarna a masculinidade que se torna hegemônica nesse contexto. Sua constante perseguição a Chiron é um comportamento caracteristicamente reativo: dentro de uma sociedade que nega a humanidade a homens negros, a opressão a outros negros aparece como uma maneira de afirmar sua identidade de forma positiva. Na narrativa do filme, ele expressa então a maneira como a masculinidade motiva a violência de negros contra negros. Os sistemas de opressão presentes na sociedade são reproduzidos dentro do grupo minoritário e isso faz com que se criem minorias dentro de minorias, grupos que são duplamente marginalizados. Mas a violência que observamos no filme não se dirige apenas àquelas pessoas que são vistas como diferentes. A masculinidade exige das pessoas um tipo de performance, mas ela também serve para estabelecer os contornos da heterossexualidade. Todos os que não se adequam a esses elementos, sejam eles heterossexuais ou homossexuais, poderão ser vítimas de violência.

O filme também oferece elementos que nos permite refletir sobre os motivos pelos quais algumas pessoas que vivem em uma situação de exclusão recorrem à delinquência e outras não. A violência dirigida a Chiron também pode ser explicada a partir da forma como a cultura patriarcal constrói a noção de masculinidade responsável. Kevin reaparece no filme em um momento no qual ele tinha acabado de sair da prisão. Ele se mostra desapontado com Chiron porque ele é agora um traficante. Kevin agora está preocupado em prover e ser uma figura responsável para sua família, o que requer uma recusa da associação com a criminalidade. Essa oportunidade parece estar longe da realidade de Chiron, um indivíduo 
que certamente enfrentaria inúmeras dificuldades em vivenciar qualquer tipo de relacionamento homossexual aberto. ${ }^{11}$

\section{O QUE UM HOMEM NEGRO PODE ESPERAR?}

Moonlight discute o tema da masculinidade hegemônica dentro do contexto de uma sociedade organizada em função de outras formas de hierarquias. Os tipos de delinquência retratados nesse filme não podem ser explicados apenas em função das disfunções presentes dentro da comunidade negra, nem por supostas disposições naturais de minorias raciais. Muitos dos comportamentos ali presentes são decorrentes dos tipos dos problemas existentes dentro de uma comunidade que é produto da segregação racial daquela sociedade. Chiron e os rapazes que o assediam são produto de uma forma de organização social que produz a segregação racial como um projeto de dominação social. A permanência desse projeto político é legitimada por uma série de estereótipos descritivos e prescritivos sobre homens negros. Os primeiros descrevem supostas características de membros desse grupo, enquanto os segundos determinam quais são os lugares que eles podem aspirar. Esses estereótipos são, portanto, formas de identidades negativas que impedem a construção de um ego integrado. A violência presente nessas comunidades não é produto de inclinações naturais da população negra, mas sim de uma série de práticas criadas para manterem o acesso privilegiado ou exclusivo de pessoas brancas a oportunidades (NIGHTGALE, 2007, p. 295-333).

0 personagem principal do filme Moonlight enfrenta um problema recorrente no processo do desenvolvimento humano: o desafio da construção de uma identidade integrada dentro de um ambiente que pode ou não oferecer as oportunidades adequadas para isso. Essa luta é particularmente difícil para ele porque esse processo se desenvolve em um ambiente de exclusão extrema, de uma realidade na qual homens negros estão excluídos do poder masculino hegemônico (MOREL, 2005, p. 92-95). 0 racismo estrutural impede a possibilidade de afirmação de um senso positivo de identidade; além disso, ele precisa também responder 
a outro tipo de demanda. Nós encontramos esse personagem quando ele ainda tem cerca de oito anos, momento no qual círculos maiores de socialização são responsáveis pelo surgimento de um conflito identitário entre a necessidade de realização decorrente de um processo satisfatório de socialização e o sentimento de inferioridade que pode surgir diante do fracasso dessa empreitada. Mas, isso não parece ser uma tarefa fácil para aquela criança. Como é comum entre moradores de bairros pobres e segregados, falta-lhe uma rede de suporte social para que ele possa dar conta das frustrações sempre presentes. Sua mãe não deixa dúvidas de que ele é um estorvo para ela, um impedimento significativo para a construção de um sentimento integrado de personalidade.

A masculinidade está relacionada com a produção do crime nessa instância mais abstrata que é a construção da negritude e mais especificamente da masculinidade negra como algo necessariamente anômico. Contudo, não se trata de inclinações naturais de grupos sociais, mas, sim, de comportamentos reativos a uma realidade que não permite que indivíduos possam desenvolver sua personalidade integrada, o que requer acesso a um repertório de identidades que não sejam aquelas que estão de antemão determinadas pela sociedade. Neste sentido, a questão da identidade pessoal ocorre dentro das relações entre a raça, a classe e o gênero do indivíduo. 0 encontro entre Kevin e Chiron quando os dois são adultos demonstra como eles seguiram caminhos que já foram percorridos por centenas de milhares de homens negros. A exclusão social produzida ao longo de disparidades de raça e classe também define a forma como pessoas podem viver a própria masculinidade. Dentro de uma realidade de grande violência, ela só pode ser vivida como uma forma de sobrevivência social; ela possui um caráter reativo, fator que aparece quando vemos Chiron adulto incorporar o protótipo de um tipo de performance que durante muito tempo produziu seu sofrimento.

Vemos então que o personagem Chiron adulto é um indivíduo que tem uma performance de gênero necessária para a sobrevivência dento do meio social no qual vive, mas essa forma de masculinidade que ele adquire para poder sobreviver dentro do mundo do crime é também uma forma de identidade capturada. Consequentemente, Chiron parece estar em uma situação de alienação ainda maior por ter que abraçar uma iden- 
tidade produzida por formas de exclusão ancorada na raça e na classe. 0 conceito de racismo estrutural é importante, aqui, para entendermos essa dinâmica da produção do crime. Um jovem que vive em uma sociedade que alimenta estereótipos raciais para legitimar arranjos sociais que permitem a reprodução do privilégio racial para brancos, um jovem que não tem acesso à educação de boa qualidade por viver em uma região segregada, na qual escolas são pior qualidade está em uma condição na qual ele não tem as oportunidades de construir um repertório de identidade que possibilite a criação de seu futuro. Os mecanismos sociais que produzem a exclusão baseada na raça e na classe agem até certo ponto de forma independente da vontade de discriminar. Uma vez criadas com essa intenção, a segregação racial produz uma cultura de classe que contribui para a exclusão social. Ela produz uma cultura de classe que dificulta de forma considerável a formação de um sentimento positivo de identidade que cria as chances do indivíduo afirmar sua própria identidade.

Como afirma Kenneth Clark (1989) em um estudo clássico sobre o tema, a segregação reproduz uma estrutura que reforça a noção de que apenas algumas direções estão abertas para os indivíduos. A construção da personalidade humana, afirma o autor, decorre da acumulação de experiências pessoais ao longo da vida; dela depende a afirmação do valor que as pessoas têm para si mesmas. A constante experiência de rejeição faz com que as pessoas comecem a duvidar da própria capacidade e da possibilidade de alcançar objetivos que elas mesmas estabelecem para si. A inexistência de representações culturais positivas faz com que membros de grupos minoritários introjetem estigmas sociais e acabem por repetir uma dinâmica que reproduz a hegemonia dos grupos raciais majoritários. 0 pequeno Little, como outras centenas de milhares de crianças, precisa resolver um problema fundamental que são os sentimentos de inferioridade relacionados com a cor da pele. A ausência de elementos identitários positivos para construir esse senso de valor pessoal em uma sociedade marcada pelo racismo cultural faz com que a criança possa formular a noção de que ela possui um valor. A baixa expectativa social faz com que ela não valorize a escolarização, o que torna difícil qualquer tipo de ascensão social que poderia quebrar o ciclo de exclusão. Isso faz com que homens negros e mulheres negras permaneçam em atividades 
profissionais com baixa remuneração, uma das causas de desestruturação familiar, problema que afetou Chiron por toda a sua vida. ${ }^{12}$

As consequências desses problemas se tornam ainda maiores na adolescência quando os jovens estão em um período de moratório moral. Esse é o momento no qual as pessoas estão definindo a vida futura baseado nas escolhas entre as oportunidades que estão disponíveis a elas. A delinquência é uma alternativa mais próxima para muitos jovens negros que vivem em uma sociedade que não apenas tem poucas expectativas positivas deles, mas também criam limites claros para as suas aspirações. A convergência entre pobreza e racismo produz sentimentos de inadequação que podem motivam o comportamento delinquente no filme em questão, o mesmo que pode ocorrer com pessoas na vida real. Mas, como a masculinidade incentiva esses jovens a procurar algum tipo de dominação, o envolvimento com o crime permite que esse desejo seja alcançado. Como nos diz Agnew, indivíduos recorrem a delinquência para eliminar fontes de frustração pessoal e Chiron agride seu colega para eliminar a humilhação que vivia cotidianamente. A passagem pelo sistema reformatório e penitenciário reduz drasticamente as chances de homem negro poder ter uma vida normal. Pelo contrário, o sistema é desenhado de tal forma que Chiron está condenado a permanecer sob a custódia estatal por quase toda a sua vida.

Certamente não podemos trabalhar com a hipótese segundo a qual moradores de bairros pobres desenvolvem uma cultura específica que os debilita, mas não podemos também eliminar a possibilidade de que muitos deles desenvolvam comportamentos estratégicos para navegar no espaço social. A hipermasculinidade do Chiron adulto pode ser vista como um exemplo disso: ele incorpora o ideal social dominante para evitar a violência que o acompanhou durante toda a vida. Ela é certamente importante para a atividade que lhe traz alguma fonte de renda, além de trazer alguma certeza para o próprio indivíduo de sua valorização pessoal. A criminalidade também parece ser uma forma do personagem afirmar sua masculinidade e diminuir sua percepção de inferioridade: ser um traficante significa ter armas, dinheiro, mulheres e poder, ou seja, uma ascensão sobre outros homens, uma vez que a criminalidade enfatiza a masculinidade. Mas, o problema presente no filme ainda destaca outro 
ponto significativo: o conflito entre essas estratégias de sobrevivência e a necessidade de desenvolvimento de certas características para a integração em uma sociedade mais ampla. Estamos aqui então diante de que tipo de transformações culturais são necessárias para a inclusão desses grupos minoritários. Elas englobam lutas contra o caráter estrutural do racismo e da homofobia, o que implica a mudança da cultura das institucionais responsáveis pela criação de sentidos e oportunidades culturais. A proposta de Nancy Fraser parece ser particularmente relevante, neste contexto, porque propõe a necessidade de criação de condições subjetivas e objetivas de paridade de participação. Se a primeira designa a necessidade de transformação das culturas das instituições sociais para que o igual respeito entre todas as pessoas seja estimulado, a segunda indica a necessidade de condições materiais de existência para que as pessoas possam ser reconhecidas como participantes competentes no espaço público.

\section{CONCLUSÃO}

Este artigo teve como objetivo demonstrar a importância do conceito de repertório identificatório para a explicação dos motivos da violência contra e também por pessoas que pertencem simultaneamente a minorias raciais e sexuais. Acreditamos que o filme Moonlight descreve de forma clara a situação de milhares de pessoas que são afetadas por formas de violência baseada na normatização das formas de expressão identitárias no espaço público. De um lado, a violência contra esses indivíduos decorre do fato de que essa instância é altamente normatizada por uma cultura heteronormativa. Do outro, observamos que ela também está presente dentro de minorias raciais, o que promove com frequência a violência contra minorias dentro de minorias. Embora as reações possam ser diversas, vemos o caso de um sujeito que incorpora essa moralidade e passa a desenvolver um comportamento estratégico que também o leva à delinquência, forma de evitar a violência física e simbólica que ele enfrentou em períodos anteriores de sua vida. Dentro desta perspectiva, parece-nos, que nos limites a que este artigo se propôs, é possível uma 
confluência entre as teorias de Agnew e Erikson, pois ambas permitem compreender a partir de perspectivas diferentes, mas complementares, a delinquência praticada por pessoas com trajetórias de vida semelhantes a de Chiron. A abordagem de Agnew permite compreender como numa sociedade de consumo as possibilidades de ascendência social para determinados grupos minoritários é praticamente impossível, sendo que a criminalidade acaba sendo a única possibilidade de obtenção de algum recurso financeiro, objetivo cultural destas sociedades. Ainda com Agnew é possível perceber que este engessamento social de determinados grupos sociais tem por resultado a frustração de seus membros que percebem suas condições de inferioridade no campo social que se apresenta como plural e democrático, resultando em estresse e emoções negativas. Por outro lado, Erikson apresenta a noção de construção da personalidade pela psicanálise e de repertório identificatório, demonstrando que em alguns grupos sociais ocorre a dupla exclusão, fato que reforça a necessidade de se desenvolver algumas performances sociais que sejam capazes de minorar os efeitos da discriminação estrutural sobre os membros dos grupos discriminados, sendo que parte dessa estratégia também pode ser a criminalidade, especialmente em casos como o do protagonista de Moonlight, que utiliza a violência, a masculidade e criminalidade como performances sociais no sentido de obter respeito e representatividade em seu meio social. Em situações de pessoas que se encontram em situação vulnerabilidade social, econômica, racial, sexual etc., especialmente em sociedades com discriminação estrutural e sem qualquer rede de proteção social à disposição destes indivíduos, parece-nos que as teorias de Agnew e Erikson oferecem um instrumental teórico satisfatório para explicar o porquê essas pessoas acabam praticando atos desviantes (crimes) e selecionadas pelas instâncias de controle social. 


\section{NOTAS}

1 Chamamos de identidades hegemônicas os traços identitários que caracterizam membros dos grupos sociais dominantes, pessoas que detem poder para estabelecer sua cultura e seus interesses como referências para a organização das diferentes organizações sociais e culturais. Isso faz com que elas se tornem requisitos para o pleno pertencimento social. Ver nesse sentido Margot Canaday. The straight state: sexuality and citizenship in twentieth century America. Princeton: Princeton University Press, 2009; Ian Haney Lopez. White by law: the legal construction of race. New York: New York University Press, 2010; Adilson José Moreira, A construção jurídica da heterossexualidade. Revista de Informação Legislativa, v. 47, n. 188, p. 45-68, 2010.

2 Ver nesse sentido S. CARRARA; G. SAGGESE. Masculinidades, violência e homofobia. In: GOMES, R. (org.), Saúde do homem em debate. Rio de Janeiro: Editora FIOCRUZ, 2011, pp. 201-225 KELLEY, K. \& GRUENEWALD, J. Accomplishing masculinity through antilesbian, gay, bisexual, and transgender homicide: a comparative case study approach. Men and Masculinities, v. 18, n. 1, p. 1-27, 2015. BUTTON, D. et al. Sexual minority youth victimization and social support: the intersection of sexuality, gender, race, and victimization. Journal of Homosexuality, v. 59, n. a, p.18-43, 2012.

3 Para uma análise pormenorizada do tema ver sobretudo Daren Lennard Hutchinson, Ignoring the sexualization of race: heteronormativity, critical race theory and anti-racist politics. Buffalo Law Review, v. 47, n.1,1999, p. 20-28 (examinando as formas como a presunção de que indivíduos são discriminados a partir de um único vetor impede o reconhecimento dos processos que tornam mecanismos de exclusão de minorias sexuais e raciais invisíveis).

4 Ver, por exemplo, Denis Oliveira, racismo midiatizado: quando o antagonismo se transforma em mera diferença. In: Celso Prudente (org.). Cinema negro. São Paulo: Editora Fiuza, 2011, p. 25-40; Denis Moraes. Crítica da mídia e hegemonia cultural. Rio de Janeiro: Mauad/ FAPERJ, 2016.

5 Para uma análise da construção da masculinidade branca como representação de superioridade racial ver sobretudo Richard Dyer, White: essays on race and culture. New York: Routledge, 1997.

6 Uma análise profunda das relações entre homossexualidade e masculinidade negra poderá ser encontrada em Patricia Hill Collins, Black sexual politics. African Americans, gender and the new racism. New York: Routledge, 2005, p. 149 - 177; Osmundo Pinho, Um enigma masculino: interrogando a masculinidade da desigualdade racial no Brasil. Universitas Humanistica, v. 77, p. 227-250, 2013.

7 Para uma análise da noção de pulsão e do desejo dentro do pensamento psicanalítico ver Sigmund Freud, Pulsões e seus destinos. Obras incompletas de Sigmund Freud. Rio de Janeiro: Autêntica, 2013; Joel Birman, Freud e a experiência da psicanalítica. Rio de Janeiro: Taurus, 1989, p. 44 - 64; Horus Vital Brazil, 0 sujeito da dúvida e a retórica do inconsciente. Rio de Janeiro: Imago, 1998, p. 139-148;

80 conceito de identidade não é um tema que possui consenso dentro da teoria psicanalítica. Embora autores como Erik Erikson e Donald Winnicott tenham enfatizado sua importância, outros psicanalistas tradição francesa apontam as dificuldades da construção de uma psicologia baseada na noção do ego. Para uma análise desse tópico ver Gilson Iannini, Estilo e verdade em Jacques Lacan. Belo Horizonte: Autêntica, 2012.

9 tema do respeito como um critério de valoração social tem sido abordado por vários autores que trabalham com a ideia segundo a qual hierarquias sociais decorrem do nível de prestígio que grupos sociais possuem. Ver sobretudo David Middleton, Three types of self-respect. Res Publica, v. 12, p. 59-76, 2006; Benjamim Eidelton, Discrimination and disrespect. Oxford: Oxford University Press, 2015.

10 Para um maior entendimento das correlações entre segregação espacial e estratificação racial ver a obra fundamental Douglas Massey; Nancy Denton. American apartheid. Segregation and the making of the underclass. Cambridge: Harvard University Press, 2003. Ver também Reinaldo José de Oliveira (org.). A cidade e o negro no Brasil. Cidadania e território. São Paulo: Alameda, 2013; Carl N. Nightingale, Segregation. A global history of divided cities. Chicago: University of Chicago Press, 2012. 
11 Um estudo sobre as discussões políticas sobre a questão da homossexualidade dentro da comunidade negra no Brasil e nos Estados Unidos ver Adilson José Moreira, Direitos fundamentais como estratégias anti-hegemônicas. Um estudo sobre a multidimensionalidade de opressões. Quaestio Juris, v. 9, n. 3, p. 1573-1579; Devon Carbado (ed.), Black men on race, gender, and sexuality. New York: New York University Press, 1999.

12 Uma discussão sobre as consequências culturais e psicológicas da segregação racial pode ser encontrada em Kenneth B. Clark. Dark ghetto. Dilemmas of social power. Hannover: Wesleyan University Press, 1989. Essa perspectiva tem sido desacreditada ao longo das últimas décadas por vários estudiosos. Ver, principalmente, Tommie Shelby. Liberalism, self-respect, and troubling cultural patterns in ghettos, In: Orlando Patterson (ed.). The cultural matrix: understanding black youth. Cambridge: Harvard University Press, 2015, p. 498-532.

\section{REFERÊNCIAS}

AGNEW, Robert. Autonomy and delinquency. Sociological Perspectives, v. 27, n. 2, 1984.

AGNEW, Robert. Building on the foundation of general strain theory: specifying the types of strain most likely to lead to crime and delinquency. Journal of Research in Crime and Delinquency, v. 38, n. 4, p. 319-361, 2001.

AGNEW, Robert. Foundations for a general strain theory of crime and delinquency. Criminology, v. 30, n. 1, p. 58 - 59. 1992.

AGNEW, Robert; WHITE, Helene Raskin. An empirical test of general strain theory. Criminology, v. 30, n. 4, p. 475 - 499, 1992.

ANITUA, Gabriel I. Historia de los pensamentos criminológicos. Buenos Aires: Editores del Puerto, 2010.

BALKIN, J. M. The constitution of status. Yale Law Journal, v. 106, v. 6, p. 2313-2374, 1997.

BALL, Matthew. Criminology and queer theory. Dangerous bedfellows? Brisbane: Palgrave Macmillan, 2016.

BARATTA, Alessandro. Criminologia crítica e crítica do direito penal: introdução à sociologia do direito penal. 3. ed. Rio de Janeiro: Revan, 2002.

BENITEZ, Maria Elvira Dias. Além de preto, viado! Etiquetando experiências e sujeitos nos mundos homossexuais. Sexualidade, v. 13, n. 24, p. 1-5, 2006. 
BIRMAN, Joel. Freud e a experiência da psicanalítica. Rio de Janeiro: Taurus, 1989.

BLUMER, Herbert. Race prejudice as a sense of group position. The Pacific Sociological Review, v. 1, n. 1, p. 3-7, 1958.

BOURDIEU, Pierre. A dominação masculina. 3. ed. Rio de Janeiro: Bertrand Brasil, 2002.

BRICKEL, Chris. Masculinities, performativity, and subversion. Men and Masculinities, v. 8, n. 1, p. 24 - 43, 2005.

BUTLER, Judity. Gender trouble: feminism and the subversion of identity. Nova York: Routledge, 1990.

BUTTON, D. et al. Sexual minority youth victimization and social support: the intersection of sexuality, gender, race, and victimization. Journal of Homosexuality, v. 59, n. a, p.18-43, 2012.

CANADAY, Margot. The straight state: sexuality and citizenship in twentieth century America. Princeton: Princeton University Press, 2009.

CARABINE, Jean. Heterosexuality and social policy. In: Diane Richardson. Theorizing heterosexuality: telling it straight. New York: Open University, 1996.

CARBADO, Devon. Black rights, gay rights, civil rights. UCLA Law Review, v. 47, n. 6, p. 1467-1520, 2000.

CARBADO, Devon (ed.). Black men on race, gender, and sexuality. New York: New York University Press, 1999.

CARBADO, Devon; GULATI, Mitu. Working identity. Cornell Law Review, v. 85, n. 5, p. 1260-1308, 1999.

CARRARA S.; SAGGESE, G. Masculinidades, violência e homofobia. In: GOMES, R. (Org.), Saúde do homem em debate. Rio de Janeiro: Editora FIOCRUZ, 2011. p. 201-225. 
CLARK, Kenneth . Dark ghetto: dilemmas of social power. 2. ed. Hannover: Wesleyan University Press, 1989.

COLLINS, Patricia Hill. Black sexual politics: African Americans, gender and the new racism. New York: Routledge, 2005. p. 149-177.

CONNEL, R. W. Masculinities. 2. ed. Berkeley: University of California Press, 2007.

CONNEL, R. W.; MESSERSCHMIDT, James W. Hegemonic masculinity: rethinking the concept. Gender and Society, v. 19, n. 6, p. 829-858, 2004.

CRENSHAW, Kimberlé. Demarginalizing the intersection of race and sex: a black feminist critique of antidiscrimination doctrine, feminist theory and antiracist policits. University of Chicago Legal Forum, v. 1989, n. 1, p. 139$167,1989$.

DARWALL, Stephen. Two kinds of respect. Ethics, v. 88, n. 1, p. 36 - 49, 1977.

DIAS, Felipe da Veiga. A violência (mortal) do Estado contra crianças e adolescentes: um estudo do retrato midiático do caso Jhonata Dalber MattosAlves.

Revista Brasileira de Ciências Criminais, São Paulo, v. 130, p. 75-114, 2017.

DYER, Richard. White: essays on race and culture. New York: Routledge, 1997.

DWYER, Angela. Policing visible sexual/gender diversity as a program of governance. International Journal for Crime and Justice, v. 1, n. 1, p. 14-26, 2012.

EIDELTON, Benjamim. Discrimination and disrespect. Oxford: Oxford University Press, 2015.

ERIKSON, Erik. Childhood and society. New York: Norton, 1963.

ERIKSON, Erik. Identidade, juventude e crise. Rio de Janeiro: Jorge Zahar, 1972.

ERIKSON, Erick. The concept of identity in race relations. Notes and queries. Daedalus, v. 95, n. 1, 1966. 
FREDMAN, Sandra. Recognition and redistribution: reconciling inequalities. South African Journal of Human Rights, v. 23, n. 2, p. 214 - 234, 2007.

FARRINGTON, David P. Age and Crime, In: TORNY, M.; MORRIS, N. (eds.). Crime and Justice: An Annual Review of Research. Chicago: University of Chicago Press, 1986.

FREUD, Sigmund. Pulsões e seus destinos: obras incompletas de Sigmund Freud. Rio de Janeiro: Autêntica, 2013.

FREUD, Sigmund. Três ensaios sobre a teoria da sexualidade. Edição standard brasileira das obras completas de Sigmund Freud. Rio de Janeiro: Imago, 1972. v. 7.

FIGUEIREDO DIAS, Jorge de; COSTA ANDRADE, Manuel. Criminologia: o homem delinquente e a sociedade criminógena. Coimbra: Editora Coimbra, 1997.

HARPER, Philipp Brian. Are we not men? Masculinity anxiety and the problem of African American identity. Oxford: Oxford University Press, 1996.

HEIMER, Karen; COSTER, Stacy De. The Gendering Of Violent Delinquency. Criminology, v. 37, n. 2, p. 277-318, 1999.

HOLER, Oystekin Gullvag. Direct gender hierarchy and structural inequality. In: M. Kimmel; J. Hearn; R. W. Connel. Handbook of studies on men and masculinities. Londres: Sage, 2005, p. 15-29.

HOOKS, Bell. We are cool: black men and masculinity. New York: Routledge, 2014

HOSKIN, Anthony. Experiencing prejudice and violence among Latinos: a general strain theory approach. Western Criminology Review, v. 14, n.1, p. 25-38, 2013.

HUTCHINSON, Daren Lennard. Ignoring the sexualization of race: heteronormativity, critical race theory and anti-racist politics. Buffalo Law Review, v. 47, n. 1, p. 3-116, 1999. 
IANNINI, Gilson. Estilo e verdade em Jacques Lacan. Belo Horizonte: Autêntica, 2012.

KELLEY, K. \& GRUENEWALD, J. Accomplishing masculinity through antilesbian, gay, bisexual, and transgender homicide: a comparative case study approach. Men and Masculinities, v. 18, n. 1, p. 1-27, 2015.

LAW, Sylvia. Homosexuality and the social meaning of gender. Wisconsin Law Review, v. 1988, n. 1, p. 187-222, 1988.

LOPEZ, Ian Haney Lopez. White by law: the legal construction of race. New York: New York University Press, 2010.

LOURY, Glenn C. The anatomy of racial inequality. Cambridge: Harvard University Press, 2002.

MARTIN, Patricia Yancey. Gender as a social institution. Social Forces, v. 82, n. 4, p. 1249 - 1273, 2004.

MASSEY, Douglas; DENTON, Nancy. American apartheid: segregation and the making of the underclass. Cambridge: Harvard University Press, 2003.

MASSEY, Douglas. Categorically unequal. The American stratification system. New York: Sage, 2007.

MERTON, Robert K. Sociologia: teoria e estrutura. São Paulo: Mestre Jou, 1972.

MERTON, Robert K. Social structure and anomie. American Sociological Review, v. 3, n. 5, p. 672-682, 1938.

MESSERSCHMIDT, W. Masculinities and crime: critique and reconceptualizan of theory. New York: Rowman \& Littlefield, Lanham, 1993.

MESSERSCHMIDT, James W. Masculinities and crime. Boston: Rowman and Littlefield, 1993.

MIDDLETON, David. Three types of self-respect. Res Publica, v. 12, p. 59$76,2006$. 
MORAES, Denis. Crítica da mídia e hegemonia cultural. Rio de Janeiro: Mauad/FAPERJ, 2016.

MOREIRA, Adilson José. A construção jurídica da heterossexualidade. Revista de Informação Legislativa, Brasília, v. 47, n. 188, p. 45-68, 2010.

Direitos fundamentais como estratégias anti-hegemônicas: um estudo sobre a multidimensionalidade de opressões. Revista Quaestio Juris, v. 9, n. 3, p. 1559-1599, 2016. 2017.

O que é discriminação? Belo Horizonte: Letramento/Justificando,

MORREL, Robert Morrel; SWART, Sandra. Men in the third world. Postcolonial perspectives on masculinity. In: M. Kimmel; J. Hearn; R. W. Connel. Handbook of studies on men and masculinities. Londres: Sage, 2005. p. 90-109.

NELSON, Todd (ed.). The handbook of prejudice, stereotyping, and discrimination. New York: Psychology Press, 2009.

NIGHTINGALE, Carl N. Segregation: a global history of divided cities. Chicago: University of Chicago Press, 2012.

OLIVEIRA, Denis. Racismo midiatizado: quando o antagonismo se transforma em mera diferença. In: Celso Prudente (Org.). Cinema negro. São Paulo: Editora Fiuza, 2011. p. 25 - 40.

OLIVEIRA, Reinaldo José de (org.). A cidade e o negro no Brasil. Cidadania e território. São Paulo: Alameda, 2013.

OWEN, David. Towards a critical analysis of whiteness. Philosophy and Social Criticism, v. 33, n. 2, 2007. p. 203-209.

PABLOS DE MOLINA, Antonio García. 0 que é criminologia? Tradução de Danilo Cymrot. São Paulo: Revista dos Tribunais, 2013.

PINHO, Osmundo. Um enigma masculino: interrogando a masculinidade da desigualdade racial no Brasil. Universitas Humanistica, v. 77, p. 227-250, 2013. 
PIQUERO, Alex R.; FARRINGTON, David P.; BLUMSTEIN, Alfred. Key Issues in criminal career research: new analyses of the Cambridge Study in delinquent development, Cambridge, U.K.: Cambridge University Press, 2007.

SOUZA, Flora Sartorelli Venâncio de. A responsabilidade do judiciário no encarceramento em massa juvenil. Revista Brasileira de Ciências Criminais, São Paulo, v. 129, p. 257-284, 2017.

SHELBY, Tommie. Liberalism, self-respect, and troubling cultural patterns in ghettos, In: Orlando Patterson (ed.). The cultural matrix: understanding black youth. Cambridge: Harvard University Press, 2015. p. 498-532.

SOUZA, Flora Sartorelli Venâncio de. A responsabilidade do judiciário no encarceramento em massa juvenil. Revista Brasileira de Ciências Criminais, São Paulo, v. 129, p. 257-284, 2017.

VITAL BRAZIL, Horus. 0 sujeito da dúvida e a retórica do inconsciente. Rio de Janeiro: Imago, 1998.

TAYLOR, Ian; WALTON, Paul; YOUNG, Jock. The new criminology: for a social theory of deviance. Nova York: Routledge, 2013.

THOMAS, Kendall. “Ain't nothin' like the real thing”. Black masculinity, gay sexuality, and the jargon of authenticity. In: Marcellus Blount; George P. Cunningham. Representing black men. New York: Routledge, 1996, p. 55 - 69.

TILLY, Charles. Durable inequality. Berkeley: University of California Press, 1998.

WELCHMAN, Kit. Erik Erikson, his life, work, and significance. Buckinghan: Open University Press, 2001.

WARD, Jane. White normativity: the cultural dimensions of whiteness in a racially diverse LBGT organization. Sociological Perspectives, v. 51, n. 3, p. 563-586, 2008.

WARE, Vron (org.), Branquidade. Identidade branca e multiculturalismo. Centro de Estudos Afro-Brasileiros/Garamond, 2004. 
WEST, Robin. Jurisprudence and gender. University of Chicago Law Review, v. 55, n. 1, p. 1-72, 1998.

Recebido em: 5-5-2018

Aprovado em: 27-11-2018

\section{Adilson José Moreira}

Doutor em Direito Constitucional Comparado pela Faculdade de Direito da Universidade de Harvard; doutor em Direito Constitucional pela Faculdade de Direito da UFMG com estágio doutoral sanduíche na Faculdade de Direito da Universidade de Yale; master of laws pela Faculdade de Direito da Universidade de Harvard; mestre em Direito Constitucional pela UFMG; professor da Faculdade de Direito da Universidade Presbiteriana Mackenzie. E-mail: ajmoreirabh@ gmail.com

\section{Humberto Barrionuevo Fabretti}

Mestre e doutor em Direito Político e Econômico pela Universidade Presbiteriana Mackenzie; professor de Criminologia, Direito Penal e Direito Processual Penal na Graduação e Pós Graduação da Faculdade de Direito da Universidade Presbiteriana Mackenzie; professor do Programa de Mestrado da Escola Paulista de Direito (EPD). E-mail: humberto.fabretti@mackenzie.br

Universidade Presbiteriana Mackenzie, Faculdade de Direito.

Rua Maria Antônia 307 - Prédio 24. Higienópolis. 30130180 - São Paulo, SP - Brasil 